\title{
Past Experiences for Future Applications of Metabolomics in Critically Ill Patients with Sepsis and Septic Shocks
}

\author{
Konlawij Trongtrakul ${ }^{1}\left(\mathbb{D}\right.$, Chanisa Thonusin ${ }^{2,3,4, *}$, Chaicharn Pothirat ${ }^{1}{ }^{(}$, Siriporn C. Chattipakorn ${ }^{2,3,5}(\mathbb{D}$ \\ and Nipon Chattipakorn $2,3,4, *$ \\ 1 Department of Internal Medicine, Faculty of Medicine, Chiang Mai University, Chiang Mai 50200, Thailand; \\ konlawij.tr@cmu.ac.th (K.T.); chaicharn.p@cmu.ac.th (C.P.) \\ 2 Metabolomics Unit, Cardiac Electrophysiology Research and Training Center, Chiang Mai University, \\ Chiang Mai 50200, Thailand; siriporn.c@cmu.ac.th \\ 3 Center of Excellence in Cardiac Electrophysiology Research, Chiang Mai University, \\ Chiang Mai 50200, Thailand \\ 4 Cardiac Electrophysiology Unit, Department of Physiology, Faculty of Medicine, Chiang Mai University, \\ Chiang Mai 50200, Thailand \\ 5 Department of Oral Biology and Diagnostic Sciences, Faculty of Dentistry, Chiang Mai University, \\ Chiang Mai 50200, Thailand \\ * Correspondence: chanisa.t@cmu.ac.th (C.T.); nipon.chat@cmu.ac.th (N.C.)
}

Citation: Trongtrakul, K.; Thonusin, C.; Pothirat, C.; Chattipakorn, S.C.; Chattipakorn, N. Past Experiences for Future Applications of Metabolomics in Critically Ill Patients with Sepsis and Septic Shocks. Metabolites 2022, 12, 1. https://doi.org/10.3390/ metabo12010001

Academic Editor: Masao Kaneki

Received: 19 November 2021

Accepted: 18 December 2021

Published: 21 December 2021

Publisher's Note: MDPI stays neutral with regard to jurisdictional claims in published maps and institutional affiliations.

Copyright: (C) 2021 by the authors. Licensee MDPI, Basel, Switzerland. This article is an open access article distributed under the terms and conditions of the Creative Commons Attribution (CC BY) license (https:// creativecommons.org/licenses/by/ $4.0 /)$.

\begin{abstract}
A disruption of several metabolic pathways in critically ill patients with sepsis indicates that metabolomics might be used as a more precise tool for sepsis and septic shock when compared with the conventional biomarkers. This article provides information regarding metabolomics studies in sepsis and septic shock patients. It has been shown that a variety of metabolomic pathways are altered in sepsis and septic shock, including amino acid metabolism, fatty acid oxidation, phospholipid metabolism, glycolysis, and tricarboxylic acid cycle. Based upon this comprehensive review, here, we demonstrate that metabolomics is about to change the world of sepsis biomarkers, not only for its utilization in sepsis diagnosis, but also for prognosticating and monitoring the therapeutic response. Additionally, the future direction regarding the establishment of studies integrating metabolomics with other molecular modalities and studies identifying the relationships between metabolomic profiles and clinical characteristics to address clinical application are discussed in this article. All of the information from this review indicates the important impact of metabolomics as a tool for diagnosis, monitoring therapeutic response, and prognostic assessment of sepsis and septic shock. These findings also encourage further clinical investigations to warrant its use in routine clinical settings.
\end{abstract}

Keywords: metabolomics; metabolism; sepsis; septic shock; critically ill patients; diagnosis; prognosis; treatment monitoring

\section{Introduction}

Sepsis is a clinical syndrome defined as a life-threatening organ dysfunction caused by a dysregulation of the host's response to infection [1]. Septic shock is a worse condition than sepsis, in which patients need vasopressor administration to maintain their mean arterial pressure over $65 \mathrm{mmHg}$, in a combination with serum lactate level greater than $2 \mathrm{mmol} / \mathrm{L}$, despite adequate volume resuscitation [1]. Sepsis and septic shock result in systemic abnormalities involved in circulatory, cellular, and metabolic failure [1], and are associated with high mortality rate, which is $25-35 \%$ of critical illness [2]. Therefore, early identification and management within a golden period, according to hour-1 bundle [3], are considered crucial to improve patients' survival. Unfortunately, conventional biomarkers, including procalcitonin and interleukin-6, have a limitation in their sensitivity and accuracy [4]. For this reason, new biomarkers are needed, and metabolomics is currently considered as a new hope for sepsis biomarkers [5]. 
Metabolomics is one of the omics sciences providing information about low molecular weight chemical compounds inside human biological specimens. This has become increasingly acknowledged in critically ill patients with sepsis and septic shock. However, the complicated alterations of various metabolic pathways in sepsis make it difficult for every single metabolite to serve as the sole biomarker for the clinical practice of sepsis. This article aims to provide an overview of metabolomic-assisted tools for critically ill patients with sepsis and septic shock in order to spot the possibility of applying metabolomics for diagnosis, monitoring of the treatment response, and prognostic evaluation of these two serious conditions. The information from this comprehensive review can contribute to further studies, integrating metabolomics with other molecular modalities and clinical manifestation, leading to the establishment of the use of a metabolomic approach in the clinical settings of sepsis and septic shock, which ultimately results in a reduction in sepsis-related mortality.

The pertinent evidence of metabolomic-assisted tools for critically ill patients with sepsis and septic shock was searched in correspondence with the assigned keywords, including 'metabolomics, adult critically ill patients, and sepsis OR septic shock' from PubMed, from its inception to May 2021. The relevant studies from this search were extracted and grouped into five issues, including the application of metabolomics for (1) sepsis diagnosis, (2) septic shock diagnosis, (3) prognostication in sepsis, (4) prognostication in septic shock, and (5) monitoring treatment response in sepsis and septic shock.

\section{The Role of Microbiota and Its Metabolites in the Development of Sepsis and Septic Shock}

Since sepsis and septic shock arise from a systemic inflammatory response to infection [6], microorganisms as infectious agents play a crucial role in the development of sepsis and septic shock. For this reason, microbial-related metabolites can be potential metabolic biomarkers to clarify the development, progression, and prognosis of sepsis and septic shock. These microbial-related metabolites include glycine, alanine, histidine, creatine, phenylalanine, 3-nitotyrosine, glutathione, glucuronic acid, gluconic acid, myoinositol, maltose, ribitol, ribonic acid, 3,4-dihydroxy-butanoic acid, 2,3,4-trihydroxybutyric acid, formic acid, 2-oxoiso-caproate, betaine, acetylacetic acid, stearic acid, oleic acid, linoleic acid, linoleic acid, 4,7,10,13,16-docosapenta-enoic acid, 4,7,10,13,16,19-docosahexaenoic acid, phenylacetic acid, phenylpropionic acid, 4-hydroxy-phenylacetic acid, homovanillic acid, 3-hydroxybutyric acid, 2-hydroxyiso-valeric acid, phenyllactic acid, 4-hydroxy-phenyllactic acid, ethanolamine, taurine, hypotaurine, phosphoethanol-amine, creatinine, proline, indoxyl sulfate, uracil, hypoxanthine, uric acid, pseudouridine, $\mathrm{N}^{1}$-methyladenosine, $\mathrm{N}^{2}, \mathrm{~N}^{2}$ dimethylguanosine, and $\mathrm{N}^{6}$-carbamoyl-threonyladenosine. Basically, all of these metabolites can be categorized into (1) amino acids and their derivatives, (2) polyols and their derivatives, (3) fatty acids and their derivatives, (4) hydroxy acids and their derivatives, (5) amines and nitrogen heterocycles, as well as (6) nitrogen-containing bases of nucleic acids, nucleosides, and their derivatives. The roles of these microbial-related metabolites have been reviewed previously, and more information can be found in that review [7].

\section{Metabolomics for Sepsis Diagnosis}

Despite limited investigation, six studies reported several metabolites which differentiated sepsis patients from their non-septic counterparts (Table 1). The elderly patients were prone to have sepsis than the young patients, and sepsis patients were more severe than those who did not have sepsis, as indicated by a higher APACHE-II score. Serum and plasma are the two common biomaterial samples [8-13]; however, one study [13] used erythrocytes for investigation in addition to plasma. Samples were mostly gathered within 24-36 $\mathrm{h}$ after the admission to ICU. According to those six reports, the common metabolic pathways that facilitated sepsis diagnosis were (1) amino acids and amines, (2) fatty acid (FA)-related metabolites, and (3) phospholipids. 
Table 1. Metabolomics-assisted diagnosis of sepsis in critically ill patients.

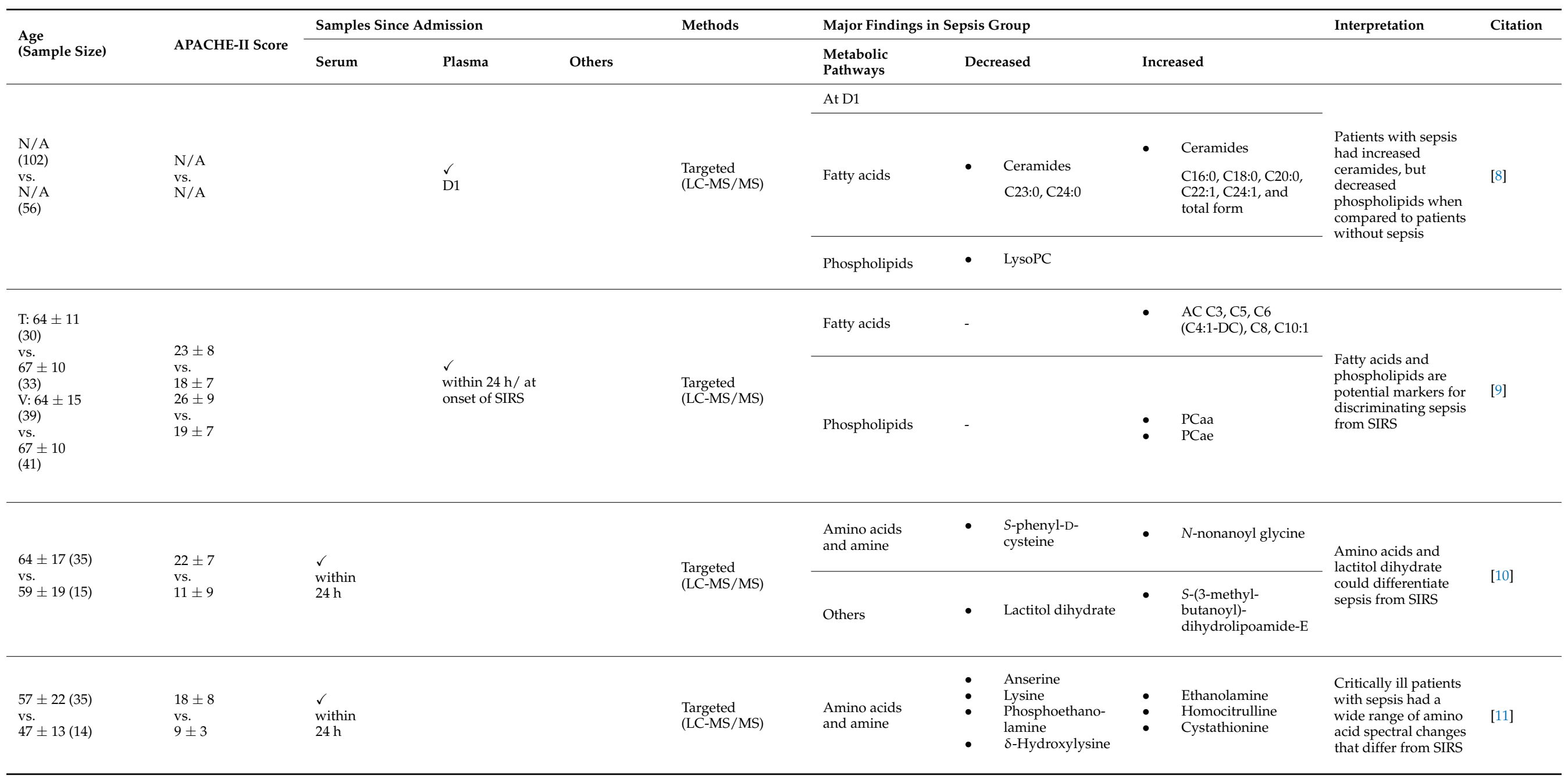


Table 1. Cont.

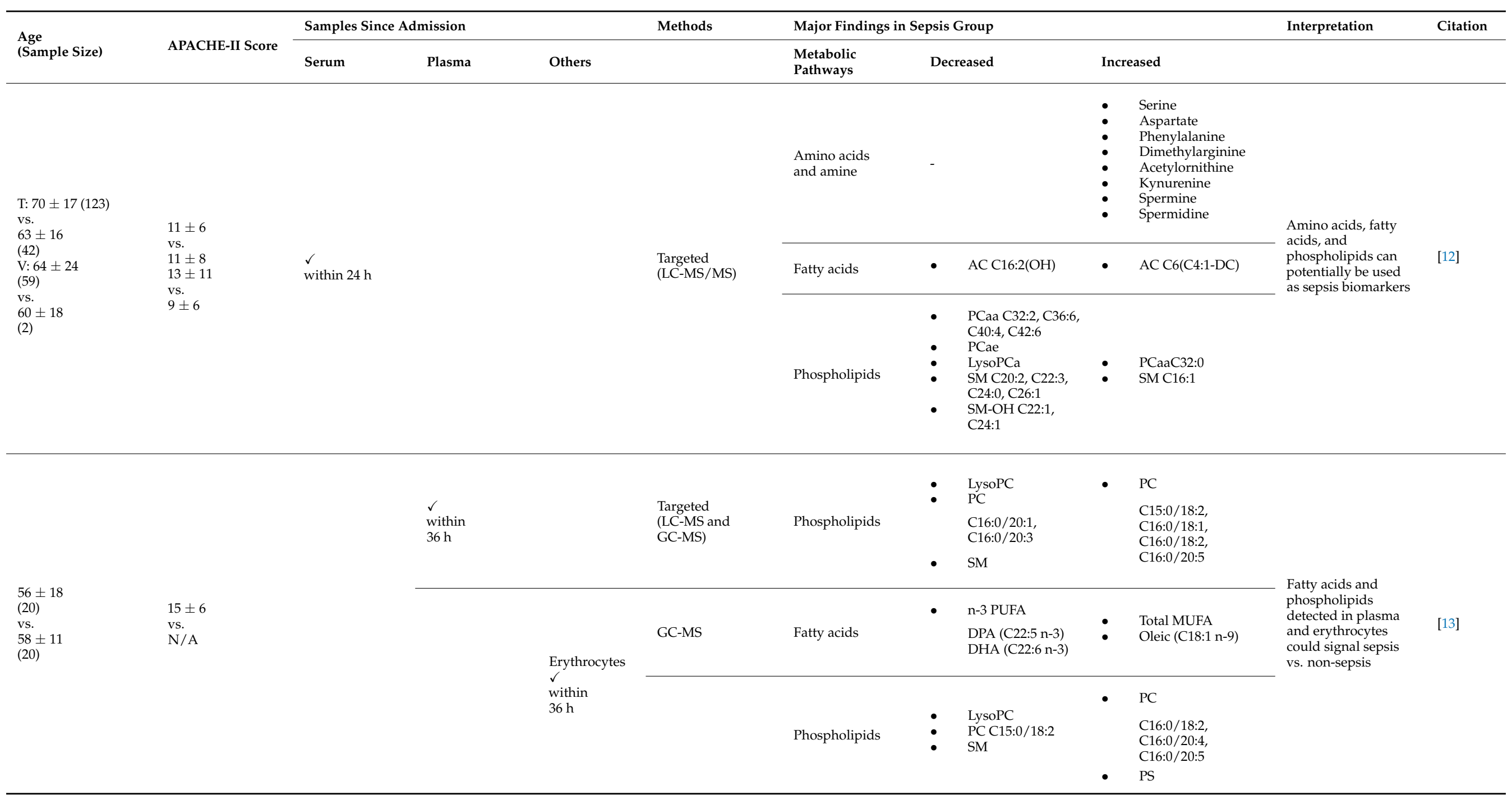

Continuous data are presented in mean \pm SD; N/A not available. Abbreviations: a, acyl; aa, diacyl; ae, acyl-akyl; AC, acylcarnitine; APACHE-II score, Acute Physiology and Chronic Health Evaluation-II score; C, number of carbons in the fatty acid side chain; DHA, docosahexaenoic acid; DPA, docosapentaenoic acid; LysoPC, lysophosphatidylcholine; LC-MS/MS, liquid chromatography-tandem mass spectrometry; MUFA, monounsaturated fatty acid; PC, phosphatidylcholine; PS, phosphatidylserine; PUFA, polyunsaturated fatty acid; SM, sphingomyelin; SIRS, systemic inflammatory response syndrome; $\mathrm{T}$, training dataset; $\mathrm{V}$, validation dataset. 


\subsection{Alterations of Amino Acids and Amines in Sepsis}

It has been shown that most amino acids were decreased during sepsis, as triggered by catabolic hormones, inflammatory mediators, and ubiquitin proteasome system [14]. Using a metabolomic approach, the changes in amino acids as a result of sepsis are comprehensively summarized in Table 1 . In sepsis, the levels of cysteine and lysine were decreased [10,11], whereas the levels of glycine, serine, polyamines, and amino acid-derived carnitines were increased due to the body's response to infection $[9,10,12]$.

\subsubsection{A Decrease in Cysteine and Lysine}

The level of cysteine and lysine were found to be decreased in sepsis patients [10]. Since cysteine is used for the synthesis of antioxidants glutathione and taurine, a reduction in cysteine suggests an increased requirement of cysteine for antioxidants synthesis to counteract oxidative stress in sepsis [15].

Indeed, lysine is involved in physiological functions for cytokines synthesis, lymphocytes proliferation, nitric oxide (NO) synthesis regulation, anti-viral infection, and antiinflammation $[11,16]$. In mice with sepsis, lysine supplementation revealed a lesser degree of inflammation and less hypotensive episodes than those received placebo [17]. However, the knowledge regarding the roles of lysine supplementation in patients with sepsis remains very limited. Future clinical studies are needed to clarify its use in septic patients.

\subsubsection{An Increase in Glycine, Serine, Polyamines, and Amino Acid-Derived Acylcarnitines}

Glycine has been shown to attenuate inflammatory response [18], and has a cytoprotective property [19]. This metabolite was increased in patients with sepsis [10]. Interestingly, glycine administration was shown to reduce hepatic injury in endotoxic shock [20]. Despite its promising benefits, limited clinical study is available. Therefore, its protective mechanism and safety dose remain to be elucidated [19].

Serine, a precursor for glucose and glycine synthesis, was found to be increased during sepsis [12]. Both glycine and serine are involved in the generation of glutathione, and are necessary for the physiological function of macrophages [21] and T lymphocytes proliferation [22]. An increment of serine in sepsis patients could be a compensatory process to counteract sepsis-induced oxidative stress [16,21].

The level of polyamines, including spermidine and spermine, were increased in patients with sepsis [12]. Two studies revealed serum [23] and polyamines, originally synthesizing from the arginine-ornithine pathway [24], to be involved in the RNA synthesis, transcription, and translation of human cells [25,26], as well as in several pathogens [24,27]. However, the interaction between host cells and the pathogen's polyamine requires elucidation. Moreover, polyamines might be markers for sepsis severity. Therefore, the correlation between polyamines levels and sepsis severity should be further investigated.

Patients with sepsis were also found to have increased levels of short-chain acylcarnitines (ACs), including $C 3$ to $C 5$ carnitines [9]. These ACs are derived mainly from branched-chain amino acids (BCAAs), which suggest an enhancement of BCAA oxidation [28] and are markers of insulin resistance [29]. Interestingly, the interplay between sepsis and insulin resistance is most commonly encountered in order to provide sufficient glucose for a cellular consumption [30]. Thus, short-chain ACs may represent the state of insulin resistance induced by sepsis as well.

\subsection{Alterations of Fatty Acids and Their Related Metabolites in Sepsis}

In sepsis, eicosanoid FAs were decreased [13]. In contrast, free monounsaturated fatty acids (MUFAs) that degrade from the cell membrane phospholipids were increased [13]. Moreover, free FA-derived ACs and ceramides were altered [8,9,12].

\subsubsection{A Decrease of Eicosanoids}

The circulating phospholipase A2 (PLA2) mediates a release of proinflammatory lipids called eicosanoids from the cell membrane phospholipids [31]. Eicosanoids are composed 
of arachidonic acid (AA) and polyunsaturated fatty acids (PUFAs) that have multiple regulatory functions involved in the inflammatory process [31]. A significant decrease in some n-3 PUFAs, including docosapentaenoic acid (C22:5 n-3) and docosahexaenoic acid $(\mathrm{C} 22: 6 \mathrm{n}-3)$, was revealed [13]. These are the precursors of anti-inflammatory mediators, called resolvins. Hence, a greater reduction in eicosanoids may reflect the degree of sepsis severity, on which a future study should be conducted to identify this relationship.

\subsubsection{An Increase in Free Fatty Acids}

A noticeable increase in MUFAs in patients with sepsis was exhibited, particularly oleic acid (18:1 n-9) [13]. This increment may be as a result of sepsis-induced lipolysis [32].

\subsubsection{An Alteration of Fatty Acid-Derived Acylcarnitines and Ceramides}

The major function of carnitines is to facilitate the transportation of long-chain fatty acids (LCFAs) from cytoplasm into the mitochondria for $\beta$-oxidation [28]. Moreover, carnitines can remove an overwhelming amount of incomplete oxidized FAs in order to prevent the intoxication of acyl-CoA [28]. In other words, increased medium-chain ACs represent increased incomplete $\beta$-oxidation. It was observed that there were alterations of $\mathrm{ACs}$ in patients with sepsis compared to those without sepsis. These changes include a decrease in long-chain ACs-C16:2(OH) carnitine [12], and an increasing level of medium-chain ACs-C6 [9,12], C8 [9], and $\mathrm{C} 10$ carnitines [9]. These findings suggested that sepsis is associated with decreased FA uptake into the mitochondria and increased incomplete $\beta$-oxidation.

Ceramides, the initial product of sphingomyelins (SMs), are another bioactive FA that play a role in the regulation of immune cells, autophagy, and apoptosis [33]. The structure of ceramide looks similar to bacterial lipopolysaccharides, which involves the pathogenesis of sepsis [34]. A reduction in C23:0 and C24:0 and an increment in C16:0, C18:0, C20:0, C22:1, and C24:1 ceramides were found in sepsis patients [8]. Additionally, an increase in the ratio of total ceramide-to-SM, as well as some specific ceramides to their SM precursor molecules, including C16:0, C18:0, C20:0, C22:0, C22:1, C23:0, C24:0, and C24:1, were revealed [8]. Indeed, increased ceramide levels could be considered to be an indicator for sepsis diagnosis.

\subsection{Alterations of Phospholipids in Sepsis}

Phospholipids are well known for a major component of cell membrane [35]. Several kinds of phospholipids are decreased in sepsis, including sphingomyelins (SMs) [13] and lysophosphatidylcholines (lysoPCs) [8,12,13], whereas cardiolipins [13] are increased. However, phosphatidylcholines (PCs) are contradictorily changed [12,13].

\subsubsection{A Decrease in Sphingomyelines and Lysophosphatidylcholines}

The level of SMs were found decreased in both plasma and erythrocyte of patients with sepsis, which included C34 to C44 SMs [13]. It is well known that inflammation triggers SM catabolism via the activation of acid sphingomyelinase enzymes, leading to increased downstream metabolites of SM, such as ceramides and PCs [36].

LysoPCs play a role in inflammation via the regulation of several immune cells, including macrophages and monocytes [37]. C16:0, C18:0, C18:1, and C18:2 lysoPCs, as well as their molar ratios corresponding to their precursor PCs, were decreased [8]. Consistently, another two studies demonstrated a reduction in lysoPCaC14:0 [12], C24:0 lysoPCs [12], and C15 to C20 lysoPCs [13]. These results suggest that it might be related to the presence of lysophospholipase D and autotaxin enzymes that hydrolyze lysoPCs [38].

\subsubsection{An Increase in Cardiolipins}

Cardiolipins are an essential lipid required for mitochondrial respiration, which are found almost in the inner membrane of mitochondria [39]. Cardiolipin was reportedly increased, as indicated by a ratio of $1^{\prime}[18: 0 / 18: 2]-$ to- $3^{\prime}$ [20:0/10:0] cardiolipin [13]. This increment reflects a cardiolipin translocation outside of a damaged mitochondria in sepsis [40]. 


\subsubsection{An Alteration of Phosphatidylcholines}

The levels of some PCs, including PCaa C32:2 [12], PCae C36:6 [12], PCae C40:4 [12], PCae C42:6 [12], PCae C44:4 [12], C16:0/20:1 PC [13], and C16:0/20:3 PC [13] were found decreased in patients with sepsis. However, the contradicted results were demonstrated. Indeed, PCaa C32:0 [9], PCae C34:1 [9], PCae C34:2 [9], PCae C36:1 [9], PCae C34:1 [9], C15:0/18:2 [13], C16:0/18:1 [13], C16:0/18:2 [13], C16:0/20:4 [13], and C16:0/20:5 [13] PCs were increased in patients with sepsis. PCs are one of the most abundant phospholipids in all cell membranes [41]. Hence, the alteration of PCs may represent the severity of sepsis-induced cellular dysfunction. In fact, it is possible that PCs can be used as a decisionmaking guide for early sepsis management in order to decrease the risk of sepsis-induced organ injury.

\section{Metabolomics for Septic Shock Diagnosis}

Two studies revealed serum and plasma [23,42] metabolites that could discriminate septic shock patients from sepsis patients without shock, as listed in Table 2. These metabolites were amino acids and amines, as well as glycolysis-related metabolites.

\subsection{Alterations of Amino Acids and Amines in Septic Shock}

A reduction in BCAAs [23,42] and urea cycle-related amino acids, including glutamine [23], glutamate [23,42], and arginine [23,42], were revealed in septic shock patients. On the other hand, aromatic amino acids (AAAs) [23,42] and proline [23,42] were increased.

\subsubsection{A Decrease in Branched-Chain Amino Acids, Glutamine, Glutamate, Arginine, and Proline}

BCAAs, including leucine, isoleucine, and valine, are categorized as essential amino acids that have a protein anabolic effect, and elicit wound healing promotion, hepatic encephalopathy prevention, and insulin secretion stimulation [43]. Two studies reported a reduction in BCAAs in their septic shock patients [23,42]. However, current evidence does not support BCAAs' supplementation in sepsis patients owing to controversial outcomes $[43,44]$. Therefore, BCAA supplementation in critically ill patients may be resolved by metabolomics study, since metabolomics may help identify the metabolism mediating the effect of BCAA supplementation on sepsis.

Glutamine is an essential amino acid that plays a role in immune function, glutathione production, and the biosynthesis of purines and pyrimidines [45]. A decrement in glutamine in septic shock patients was demonstrated from a single study [23]. This finding may reflect increased glutamine consumption that exceeds the rate of biosynthesis in sepsis $[43,45]$.

Glutamate has functions for preserving nitrogen balance in skeletal muscle [45] and promoting the clearance of nitrogen waste products in the liver before excretion via the kidney $[46,47]$. Moreover, glutamate can convert into $\alpha$-ketoglutarate, which is one of the energy sources in the TCA cycle. Both studies revealed a decrease in the glutamate level of their septic shock patients [23,42], which is likely to be a result of low dietary intakes and hepatic glutamate synthesis, as well as an increase in glutamate consumption $[46,48]$.

Arginine, one of intermediate amino acids in the urea cycle, has a pertinent role in the biosynthesis of protein, $\mathrm{NO}$, creatine, urea, and polyamines [49,50]. A decrease in the arginine levels of septic shock patients was demonstrated in both studies [23,42]. Although a low level of arginine is associated with sepsis, its supplementation remains a controversial issue [51]. Indeed, some benefits were shown in trauma and critically ill surgical patients [52]. However, in sepsis shock patients, worsening hemodynamic instability is aggravated, as arginine can turn into NO $[49,50]$.

Proline functions to regulate the cellular redox state, promote lymphocytes proliferation, eradicate pathogens via superoxide formation, advocate wound healing, and is involved in ornithine and polyamine formation via pyrroline-5-carboxylate (P5C) [16]. Proline was decreased in septic shock patients from both studies [23,42]. This result might represent the promotion of tissue repair during sepsis [53]. 
Table 2. Metabolomics-assisted diagnosis of septic shock in critically ill patients.

\begin{tabular}{|c|c|c|c|c|c|c|c|c|c|}
\hline \multirow{2}{*}{$\begin{array}{l}\text { Age (Age Range) } \\
\text { (Sample Size) }\end{array}$} & \multirow{2}{*}{$\begin{array}{l}\text { APACH-II } \\
\text { Score }\end{array}$} & \multicolumn{2}{|c|}{ Samples Since Admission } & \multirow[b]{2}{*}{ Methods } & \multicolumn{3}{|c|}{ Major Findings in Septic Shock Groups } & \multirow{2}{*}{ Interpretation } & \multirow{2}{*}{ Citation } \\
\hline & & Serum & Plasma & & $\begin{array}{l}\text { Metabolic } \\
\text { Pathways }\end{array}$ & Decreased & Increased & & \\
\hline \multirow{4}{*}{$\begin{array}{l}62(55-73) \\
(39) \\
\text { vs. } \\
66(56-71) \\
(20)\end{array}$} & \multirow{4}{*}{$\begin{array}{l}23(16-31) \\
\text { vs. } \\
14(13-17)\end{array}$} & \multirow{4}{*}{$\begin{array}{l}\checkmark \\
\text { within } \\
24 \mathrm{~h}\end{array}$} & & \multirow[t]{4}{*}{$\begin{array}{l}\text { Targeted } \\
\left({ }^{1} \mathrm{H}-\mathrm{NMRS}\right)\end{array}$} & $\begin{array}{l}\text { Amino acids } \\
\text { and amines }\end{array}$ & $\begin{array}{ll}\text { - } & \text { Isoleucine } \\
\text { - } & \text { Glutamine } \\
\text { - } & \text { Alanine } \\
\text { - } & \text { Leucine } \\
\text { - } & \text { Glycine } \\
\text { - } & \text { Serine } \\
: \quad \text { Threonine } \\
\text { - } & \text { Gline } \\
\text { - } & \text { Argininine } \\
\quad \text { 2-Aminobutyrate }\end{array}$ & $\begin{array}{ll}\text { - } & \text { Phenylalanine } \\
\text { - } & \text { 2-Hydroxy- } \\
\text { - } & \text { isovalerate } \\
\text { - } & \text { Proline } \\
& \text { Trimethylamine } \\
& \text {-oxide }\end{array}$ & \multirow{4}{*}{$\begin{array}{l}\text { Septic shock patients } \\
\text { had different patterns } \\
\text { in amino acids, fatty } \\
\text { acids, and TCA cycle } \\
\text { metabolites }\end{array}$} & \multirow{4}{*}[23]{} \\
\hline & & & & & Fatty acids & - & - Isobutyrate & & \\
\hline & & & & & Glycolysis & $\begin{array}{ll}\text { - } & \text { Glucose } \\
& \text { Mannose }\end{array}$ & $\begin{array}{ll}\text { - } & \text { Lactate } \\
\text { - } & \text { Sucrose } \\
\text { - } & \text { Myoinositol } \\
& \text { AC C2 }\end{array}$ & & \\
\hline & & & & & TCA cycle & - & - Succinate & & \\
\hline \multirow{2}{*}{$\begin{array}{l}62(56-73)(37) \\
\text { vs. } \\
66(56-71)(20)\end{array}$} & \multirow{2}{*}{$\begin{array}{l}23(16-31) \\
\text { vs. } \\
14(13-17)\end{array}$} & \multirow{2}{*}{$\begin{array}{l}\checkmark \\
\text { within } 24 \mathrm{~h}\end{array}$} & \multirow{2}{*}{$\begin{array}{l}\checkmark \\
\text { within } \\
24 \mathrm{~h}\end{array}$} & \multirow{2}{*}{$\begin{array}{l}\text { Targeted } \\
\left({ }^{1} \mathrm{H}-\mathrm{NMRS}\right)\end{array}$} & $\begin{array}{l}\text { Amino acids } \\
\text { and amines }\end{array}$ & $\begin{array}{ll}\text { - } & \text { Threonine } \\
\text { - } & \text { Valine } \\
\text { - } & \text { Arginine } \\
& \text { Glutamate }\end{array}$ & $\begin{array}{l}\text { - } \quad \text { Phenylalanine } \\
\text { - Proline }\end{array}$ & \multirow{2}{*}{$\begin{array}{l}\text { Septic shock patients } \\
\text { had different patterns } \\
\text { of metabolites, } \\
\text { particularly } \\
\text { amino acids }\end{array}$} & \multirow[t]{2}{*}[42]{} \\
\hline & & & & & Glycolysis & - $\quad$ Glucose & $\begin{array}{ll}\text { - } & \text { Myoinositol } \\
\text { AC C2 }\end{array}$ & & \\
\hline
\end{tabular}




\subsubsection{An Increase in Aromatic Amino Acids}

Phenylalanine, tyrosine, and tryptophan are categorized as AAAs [54,55]. Phenylalanine has an important function for producing tetrahydrobiopterin $(\mathrm{BH} 4)$ cofactor, which is involved in arginine-NO synthesis [56,57]. Although the increment in phenylalanine was reported in septic shock [23,42], the information of tyrosine and tryptophan alteration remained unknown. For this reason, a metabolomics study quantifying a whole AAA metabolic pathway in sepsis and septic shock should be established.

\subsection{Alterations of Glycolysis-Related Metabolites in Septic Shock}

Hypoglycemia was found in both studies [23,42]. This phenomenon could be a result of low dietary intake, a decrease in gluconeogenesis, the depletion of glycogen, or an increase in peripheral consumption [32]. Furthermore, a decrease in mannose and an increase in sucrose and myo-inositol were found [23,42]. Although it is difficult to explain the exact role of these sugars, the alterations may be modulated by the organism, rather than the body's response to infection.

Acetylcarnitine (C2 carnitine) represents a cycling of acetyl-CoA, which is a product of glycolysis [58]. C2 carnitine was found elevated in patients with septic shock [23,42], owing to an excess acetyl group from metabolic stress that may intoxicate the cell [59].

\section{Metabolomics for Prognostication Patients with Sepsis}

Nine studies reporting numerous metabolites that could prognosticate patients with sepsis non-survivors at $48 \mathrm{~h}$ after the ICU admission through day 90 [8,10,11,60-66]. Almost patients had sepsis, non-survivors were older $[8,10,11,61,62,64-66]$, with a greater severity of illness [10,11,60-66]. Plasma was a specimen of choice for a targeted metabolomic approach $[8,11,60-64,66]$. The metabolites that help prognosticate non-survivors with sepsis are listed as the following.

\subsection{Alterations of Amino Acids and Amines in Sepsis Non-Survivors}

It was shown that taurine, tryptophan, glutamate, arginine, and serine were decreased in non-surviving patients with sepsis [11]. In contrast, intermediate metabolites of amino acids, including S-(3-methyl-butanoyl)-dihydrolipoamide-E [10], amino acidderived carnitines [61,62], symmetric dimethylarginine (SDMA) [61,66], and asymmetric dimethylarginine (ADMA) [66], were found to be increased in non-surviving patients with sepsis. The details are shown in Table 3. 
Table 3. Metabolomics-assisted prognostication of patients with sepsis non-survivors.

\begin{tabular}{|c|c|c|c|c|c|c|c|c|c|c|c|}
\hline \multirow{2}{*}{ Settings } & \multirow{2}{*}{$\begin{array}{l}\text { Age (Age } \\
\text { Range) } \\
\text { (Sample Size) }\end{array}$} & \multirow{2}{*}{$\begin{array}{l}\text { APACHE-II } \\
\text { Score }\end{array}$} & \multicolumn{3}{|c|}{ Samples Since Admission } & \multirow[b]{2}{*}{ Methods } & \multicolumn{3}{|c|}{ Major Findings in Non-Survivors } & \multirow[t]{2}{*}{ Interpretation } & \multirow[t]{2}{*}{ Citation } \\
\hline & & & Serum & Plasma & Blood & & $\begin{array}{l}\text { Metabolic } \\
\text { Pathways }\end{array}$ & Decreased & Increased & & \\
\hline \multirow{2}{*}{$\begin{array}{l}48-\mathrm{H} \\
\text { mortality }\end{array}$} & \multirow{2}{*}{$\begin{array}{l}67 \pm 15(9) \\
\text { vs. } \\
63 \pm 18(26)\end{array}$} & \multirow{2}{*}{$\begin{array}{l}26 \pm 6 \\
\text { vs. } \\
20 \pm 8\end{array}$} & \multirow{2}{*}{$\begin{array}{l}\checkmark \\
\text { within } 48 \text {-H } \\
\text { before } \\
\text { death }\end{array}$} & & & \multirow{2}{*}{$\begin{array}{l}\text { Targeted } \\
\text { (LC-MS/MS) }\end{array}$} & $\begin{array}{l}\text { Amino acids } \\
\text { and amines }\end{array}$ & - & $\begin{array}{l}\text { - } \quad \text { S-(3-methyl- } \\
\text { butanoyl)dihydro- } \\
\text { lipoamide-E }\end{array}$ & \multirow{2}{*}{$\begin{array}{l}\text { Amino acids and } \\
\text { phospholipids } \\
\text { could indicate } \\
\text { the possibility of } \\
\text { death within } \\
\text { 48-H in patients } \\
\text { with sepsis }\end{array}$} & \multirow{2}{*}[10]{} \\
\hline & & & & & & & Phospholipids & - & $\begin{array}{ll}\text { - } & \text { Phosphatidyl-glycerol(22:2 } \\
\text { - } & (13 Z, 16 Z) / 0: 0) \\
\text { GPC }\end{array}$ & & \\
\hline \multirow{10}{*}{ 7-D mortality } & \multirow{10}{*}{$\begin{array}{l}60(36-80) \\
(9) \\
\text { vs. } \\
60(27-84) \\
(13)\end{array}$} & \multirow{10}{*}{$\begin{array}{l}31(16-46) \\
\text { vs. } \\
22(14-38)\end{array}$} & & \multirow{10}{*}{$\begin{array}{l}\checkmark \\
\text { within } 48 \mathrm{~h} \\
=\mathrm{D} 1, \mathrm{D} 3 \\
\text { and D7 }\end{array}$} & & \multirow{10}{*}{$\begin{array}{l}\text { Targeted } \\
\text { (LC-MS/MS) }\end{array}$} & Fatty acids & - & $\begin{array}{ll}\text { - } & \text { Prostaglandin F2 } \alpha \\
\bullet & \text { Leukotriene B4 } \\
\bullet & \text { Resolvin E1 } \\
\text { - } & \text { Resolvin D5 } \\
& \text { 17R-Protectin D1 }\end{array}$ & \multirow{10}{*}{$\begin{array}{l}\text { Fatty acids and } \\
\text { proresolving } \\
\text { lipids signal 7-D } \\
\text { mortality in } \\
\text { critically-ill } \\
\text { patients } \\
\text { with sepsis }\end{array}$} & \multirow{10}{*}[60]{} \\
\hline & & & & & & & At D1 & & & & \\
\hline & & & & & & & Fatty acids & - & $\begin{array}{ll}\text { - } & \text { 7-HDHA } \\
\text { : } & 17-\text {-HDHA } \\
\text { : } & 18 \text {-HEPE } \\
& 15 \text {-HETE }\end{array}$ & & \\
\hline & & & & & & & & - & - $\quad$ Protectin D1 & & \\
\hline & & & & & & & At D3 & & & & \\
\hline & & & & & & & Fatty acids & - & $\begin{array}{ll}\bullet & \text { 17-HDHA } \\
: & \text { 18-HEPE } \\
: & \text { 5-HETE } \\
\bullet & \text { 5S,12S-diHETE }\end{array}$ & & \\
\hline & & & & & & & & - & $\begin{array}{ll}\text { - } & \text { 17-epi-Resolvin D1 } \\
\text { 17-epi-Protectin D1 }\end{array}$ & & \\
\hline & & & & & & & At D7 & & & & \\
\hline & & & & & & & Fatty acids & - & $\begin{array}{ll}\bullet & \text { 4S,14S-diHDHA } \\
\bullet & \text { 5S,15S-diHETE }\end{array}$ & & \\
\hline & & & & & & & & - & - Resolvin E2 & & \\
\hline
\end{tabular}


Table 3. Cont.

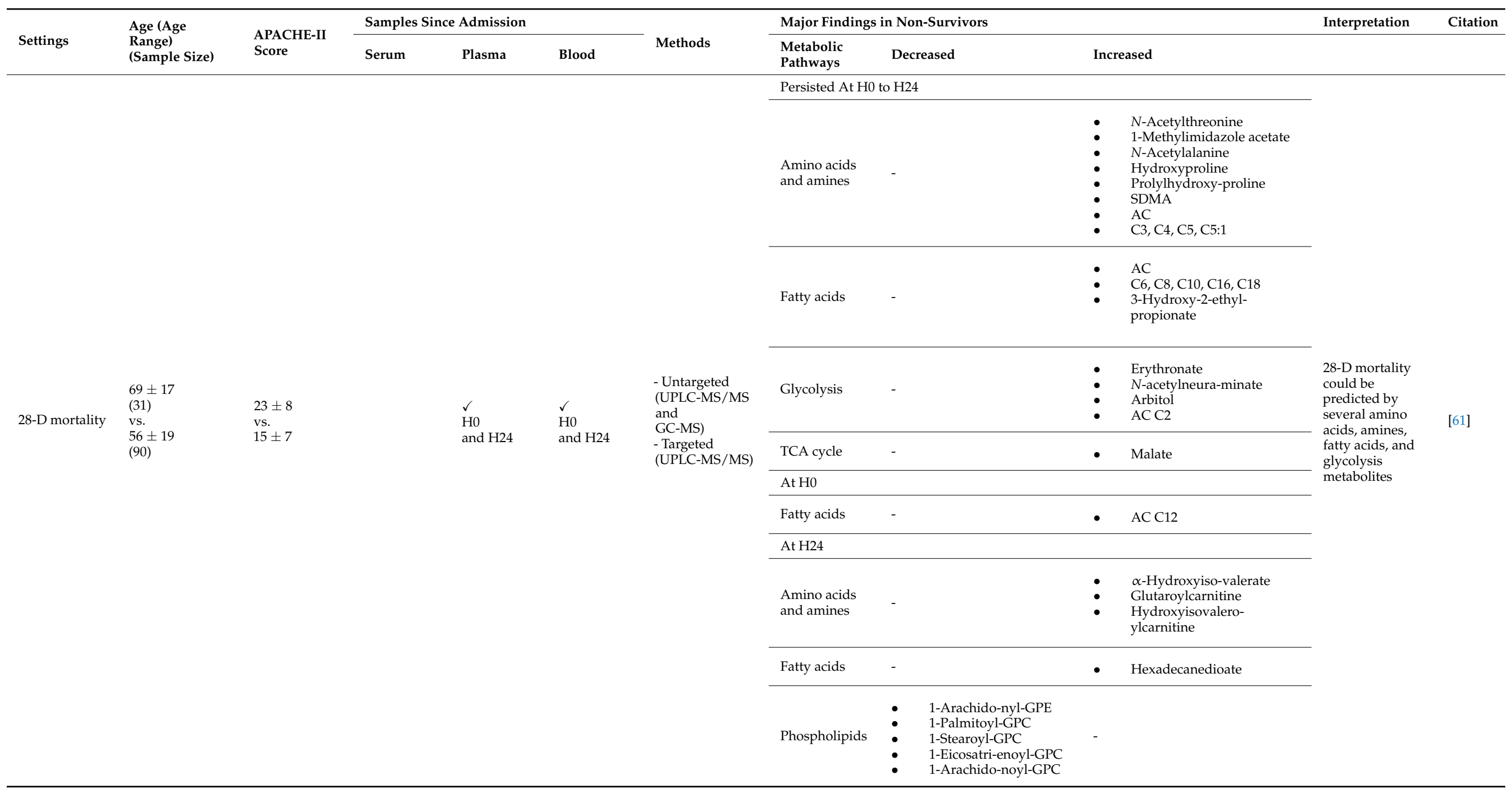


Table 3. Cont.

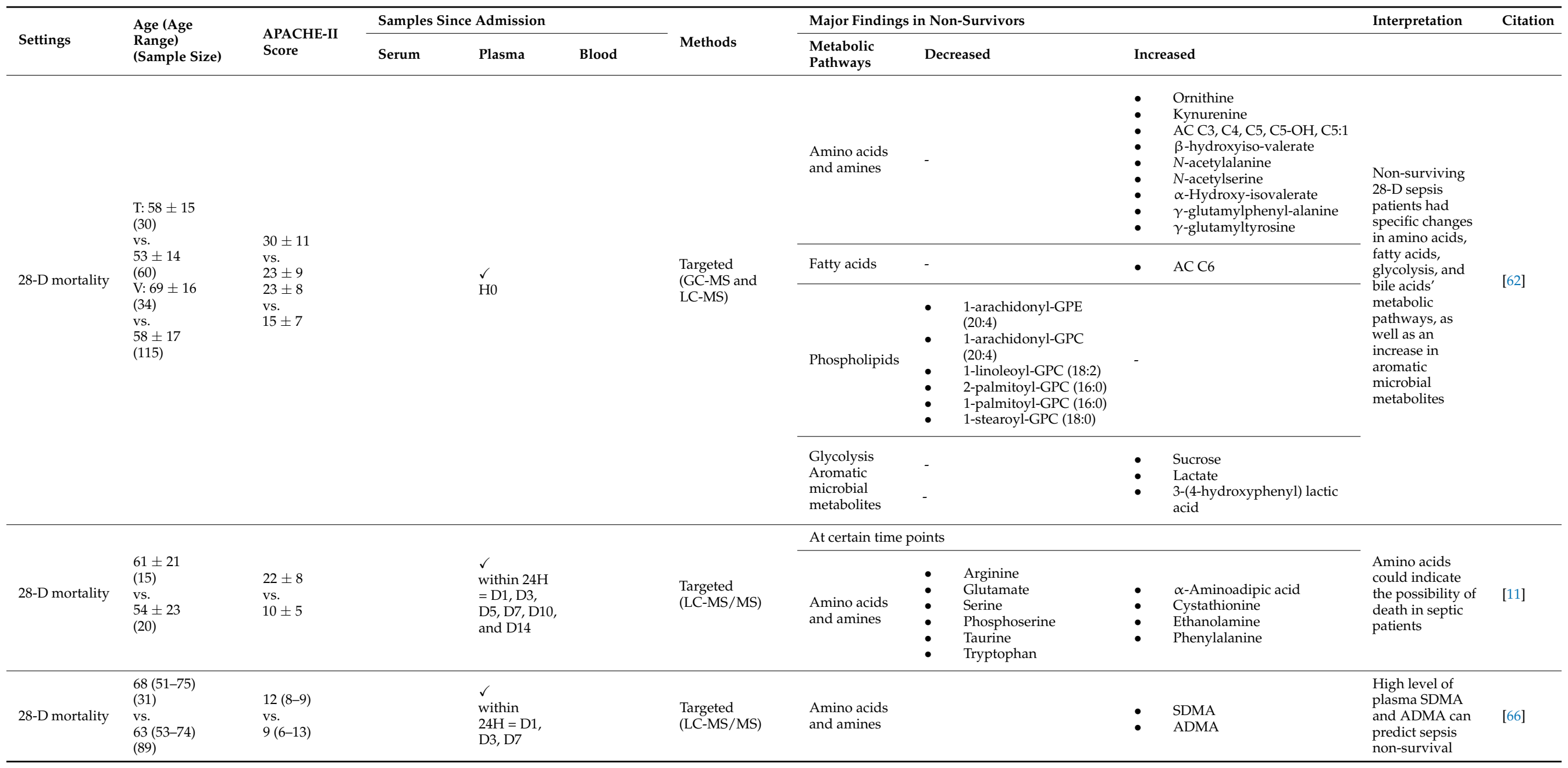


Table 3. Cont.

\begin{tabular}{|c|c|c|c|c|c|c|c|c|c|c|c|}
\hline \multirow[b]{2}{*}{ Settings } & \multirow{2}{*}{$\begin{array}{l}\text { Age (Age } \\
\text { Range) } \\
\text { (Sample Size) }\end{array}$} & \multirow{2}{*}{$\begin{array}{l}\text { APACHE-II } \\
\text { Score }\end{array}$} & \multicolumn{3}{|c|}{ Samples Since Admission } & \multirow[b]{2}{*}{ Methods } & \multicolumn{3}{|c|}{ Major Findings in Non-Survivors } & \multirow[t]{2}{*}{ Interpretation } & \multirow[t]{2}{*}{ Citation } \\
\hline & & & Serum & Plasma & Blood & & $\begin{array}{l}\text { Metabolic } \\
\text { Pathways }\end{array}$ & Decreased & Increased & & \\
\hline 28-D mortality & $\begin{array}{l}70 \pm 13 \\
(21) \\
\text { vs. } \\
72 \pm 15 \\
(69) \\
\end{array}$ & $\begin{array}{l}26 \pm 9 \\
\text { vs. } \\
23 \pm 8\end{array}$ & & $\begin{array}{l}\checkmark \\
\text { H0 }\end{array}$ & & $\begin{array}{l}\text { Targeted } \\
\text { (UHPLC-MS) }\end{array}$ & Glycolysis & - & - $\quad \mathrm{ACC} 2$ & $\begin{array}{l}\text { Acetylcarnitine } \\
\text { can forecast } \\
\text { 28-D mortality } \\
\text { in patients } \\
\text { with sepsis }\end{array}$ & [63] \\
\hline \multirow{2}{*}{ 28-D mortality } & \multirow{2}{*}{$\begin{array}{l}67 \pm 14 \\
(54) \\
\text { vs. } \\
62 \pm 19 \\
(134)\end{array}$} & \multirow{2}{*}{$\begin{array}{l}22(18-30) \\
\text { vs. } \\
18(13-24)\end{array}$} & & \multirow{2}{*}{$\begin{array}{l}\checkmark \\
\mathrm{H} 0\end{array}$} & & \multirow{2}{*}{$\begin{array}{l}\text { Targeted } \\
\text { (LC-MS) }\end{array}$} & $\begin{array}{l}\text { Amino acids } \\
\text { and amines }\end{array}$ & - & $\begin{array}{ll}\text { - Isoleucine } \\
\text { - Alanine }\end{array}$ & \multirow{2}{*}{$\begin{array}{l}\text { Particular } \\
\text { metabolites can } \\
\text { forecast 28-D } \\
\text { mortality in } \\
\text { sepsis patients }\end{array}$} & \multirow{2}{*}{ [64] } \\
\hline & & & & & & & Glycolysis & - & $\begin{array}{ll}\text { - } & \text { Lactate } \\
\text { - } & \text { Pyruvate } \\
\text { AC C2 }\end{array}$ & & \\
\hline \multirow[b]{2}{*}{ 30-D mortality } & \multirow{2}{*}{$\begin{array}{l}55(17-80) \\
(39) \\
\text { vs. } \\
54(20-91) \\
(63)\end{array}$} & \multirow[b]{2}{*}{$\begin{array}{l}\text { N/A } \\
\text { vs. } \\
\text { N/A }\end{array}$} & & \multirow[b]{2}{*}{$\begin{array}{l}\checkmark \\
\text { D1, D4, } \\
\text { and D11 }\end{array}$} & & \multirow[b]{2}{*}{$\begin{array}{l}\text { Targeted } \\
\text { (LC-MS/MS) } \\
\text { Lipids }\end{array}$} & \multicolumn{3}{|c|}{ Persisted along D1 to D11 } & & \multirow[b]{2}{*}{ [8] } \\
\hline & & & & & & & $\begin{array}{l}\text { Fatty acids } \\
\text { and } \\
\text { phospholipids }\end{array}$ & - & $\begin{array}{l}\text { Total ceramides-to-SM } \\
\text { ratio/total LysoPC-to-PC } \\
\text { ratio }\end{array}$ & & \\
\hline
\end{tabular}

Continuous data are presented in mean $\pm \mathrm{SD}$, otherwise reported as median and IQR1-3. \$ Sequential Organ Failure Assessment (SOFA) score. Abbreviations: 7-HOCA, 7$\alpha$-hydroxy-3-oxo-4-cholestenoate; APACHE-II score, Acute Physiology and Chronic Health Evaluation-II score; ADMA, asymmetric dimethylarginine; C, number of carbons in the fatty acid side chain; D, Day; GPC, Glycerophosphocholine; GPE, Glycerophosphoethanolamine; H, Hour; HDHA, Hydroxydocosahexaenoate; HEPE; Hydroxyeicosapentaenoate; HETE; Hydroxyeicosatetraenoate; LysoPC, lysophosphatidylcholine; LC-MS/MS, liquid chromatography-tandem mass spectrometry; SDMA, symmetric dimethylarginine; taenoate; HETE; Hydroxyeicosatetraenoate; LysoPC, lysophosphatidylcholine; LC-MS/MS, liquid chromatography-tandem mass spectrometry; SDMA, symmetric dimethylarginine;
UHPLC-MS, Ultra-high performance liquid chromatography mass spectrometry; UPLC-MS, Ultra-performance liquid chromatography-mass spectrometry; T, training cohort; $\mathrm{V}$, validation cohort. 


\subsubsection{A Decrease in Taurine, Tryptophan, Glutamate, Arginine, and Serine}

Taurine, a sulfur-containing amino acid that most abundant in leukocytes, is recognized as an antioxidant, and exerts an antimicrobial effect $[16,67]$. Moreover, a decreased level of taurine was associated with hyperlactatemia and cardiopulmonary dysfunction [68]. One study reported a reduction in taurine in non-surviving patients with sepsis at day 28 [11]. Nonetheless, taurine supplementation in sepsis patients revealed promising results in terms of decreasing IL-6 and improving clinical outcomes [69].

One study showed a decreased level of tryptophan associated with sepsis mortality at day 28 [11]. A reduction in tryptophan reflects the increased tryptophan degradation to be kynurenine owing to cytokines release [70], and is considered to be one of the main mechanisms of hypotension in sepsis [71]. Correspondingly, a study showed an increased level of kynurenine in patients with sepsis non-survivors at day 28 [62]. Taken together, a decrease in tryptophan and an increase in kynurenine level may be potential factors with which to determine the severity of sepsis. Moreover, tryptophan can be metabolized to be serotonin and melatonin [72], which attenuate the inflammatory response and play a significant role in the regulation of mood, circadian rhythm, and sleep [73]. A supplementation of tryptophan in critical illness may decrease the incidence of sleep deprivation and delirium, which are common problems in critically ill patients [74]. Thus, future studies are needed to answer this question.

Glutamate, arginine, and serine were decreased in sepsis non-survivors at day 28 [11]. Interestingly, serine alteration was different between study populations. It was decreased in non-surviving patients with sepsis at day 28 [11] but was increased in patients with sepsis, as previously mentioned in Section 3.1.2 [12]. An overwhelming utilization of serine in sepsis non-survivors might explain this finding.

5.1.2. An Increase in S-(3-Methyl-butanoyl)-dihydrolipoamide-E, Amino Acid-Derived Acylcarnitines, and Symmetric Dimethylarginine and Asymmetric Dimethylarginine

$S$-(3-methyl-butanoyl)-dihydrolipoamide-E is an intermediate metabolite of leucine degradation [75]. One study demonstrated an increase in this metabolite in non-surviving patients with sepsis within $48 \mathrm{~h}$ of admission [10]. Moreover, an increase in short-chain ACs: C3, C4, C5, C5-OH, and C5:1 carnitines were observed in non-surviving patients with sepsis at day 28 [61,62]. These increments may be related to an abnormality in BCAA synthesis and degradation. However, further metabolomic studies covering all metabolites in BCAA synthesis and short-chain ACs production are needed to identify which steps of BCAAs are disrupted in septic non-survivors.

SDMA and ADMA are residual from a broken-down arginine process [76] and are considered as competitive inhibitors of NO synthesis [77]. Based on mortality at day 28, prior studies demonstrated a higher level of SDMA and ADMA at day 1 [61,66], 3 [66], and 7 [66] in sepsis non-survivors than the survivors. These results might suggest an excessive production of $\mathrm{NO}$ in septic shock non-survivors.

\subsection{Alterations of Fatty Acids and Their Related Metabolites in Sepsis Non-Survivors}

Non-surviving patients with sepsis at day 7 had an increase in several lipid mediators [60]. Specifically, AA-derived FAs, including prostaglandin F2 $\alpha$ and leukotriene B4, and specialized pro-resolution lipid mediators including 17R-protectin D1, resolvin D5, and resolvin E1, were persistently elevated along a study period of 7 days [60]. It is well known that lipid mediators, particularly prostaglandin and leukotriene, enhance vasodilatation and inflammation [78], which may ameliorate by non-steroidal, anti-inflammatory drugs $[79,80]$. However, a vulnerability to acute kidney injury in critically illness [81,82] limits the feasibility of using NSAIDs in the case of most septic patients. Further study is needed to establish the appropriate medications to counteract the devastated lipid mediators. 
In addition, non-surviving patients with sepsis at day 28 had an increase in FA-derived ACs, including medium-chain ACs (C6, C8, C8:1, and C12 carnitines) and long-chain ACs (C16 and C18 carnitines) [61]. The results suggested that sepsis non-survivors have an increased FA uptake, but incomplete $\beta$-oxidation [83].

\subsection{Alteration of Phospholipids in Sepsis Non-Survivors}

Several phospholipids were decreased in patients with sepsis non-survivors at day 28 including C22:0 and C24:0 lysoPCs [64], and 1-arachidonoyl-glycerophosphoethanolamine (20:4) [62]. However, phosphatidylglycerol (22:2(13Z,16Z)/0:0) and glycerophosphocholine (GPC) were found to be increased in the non-survivors at $48 \mathrm{~h}$ after the ICU admission [10].

\subsection{Alterations of Glycolysis-Related Metabolites in Sepsis Non-Survivors}

Pyruvate and lactate were increased in sepsis non-survivors at day 28 [64]. Instead of entering into the TCA cycle, pyruvate accumulation can convert to lactate when tissue is confronted with poor perfusion [84].

\subsection{Alterations of Aromatic Microbial Metabolites in Sepsis Non-Survivors}

It was demonstrated that plasma 3-(4-hydroxyphenyl) lactic acid was positively associated with death from sepsis at day 28 [62]. This metabolite is classified as an aromatic microbial metabolite that has been shown to be involved in the pathogenesis of septic shock [85]. Therefore, these reports emphasize the impact of microbiota on the development and progression of sepsis.

\section{Metabolomics for Prognostication Patients with Septic Shock}

Meaningful metabolites that can prognosticate septic shock non-survivors since ICU admission to 1 year after hospital discharge are reported from seven studies (Table 4) [42,86-91]. Most of the studies demonstrated that non-survivors were older and severer than those survivors [86-88,90,91]. Serum or plasma remained the samples for a targeted metabolomics study [42,86-89]. Furthermore, some studies revealed a dynamic change in metabolite levels over the study period [88,89]. The metabolites that helped prognosticating septic shock non-survivors including amino acids and amines, fatty acids, phospholipids, glycolysis-related metabolites, and TCA cycle metabolites. 
Table 4. Metabolomics-assisted prognostication of patients with septic shock non-survivors.

\begin{tabular}{|c|c|c|c|c|c|c|c|c|c|c|c|}
\hline \multirow{2}{*}{ Settings } & \multirow{2}{*}{$\begin{array}{l}\text { Age (Age } \\
\text { Range) } \\
\text { (Sample Size) }\end{array}$} & \multirow{2}{*}{$\begin{array}{l}\text { APACHE-II } \\
\text { Score }\end{array}$} & \multicolumn{3}{|c|}{ Samples Since Admission } & \multirow[b]{2}{*}{ Methods } & \multicolumn{3}{|c|}{ Major Findings in Non-Survivors (NS) } & \multirow[b]{2}{*}{ Interpretation } & \multirow[b]{2}{*}{ Citation } \\
\hline & & & Serum & Plasma & Urine & & $\begin{array}{l}\text { Metabolic } \\
\text { Pathways }\end{array}$ & Decreased & Increased & & \\
\hline \multirow{3}{*}{ ICU mortality } & \multirow{3}{*}{$\begin{array}{l}63(60-77) * \\
(8)^{*}\end{array}$} & \multirow{3}{*}{$26(18-31) *$} & \multirow{3}{*}{$\begin{array}{l}\checkmark \\
\text { within } \\
24 \mathrm{~h}\end{array}$} & \multirow{3}{*}{$\begin{array}{l}\checkmark \\
\text { within } 24 \mathrm{~h}\end{array}$} & & \multirow{3}{*}{$\begin{array}{l}\text { Targeted } \\
\left({ }^{1} \mathrm{H}-\mathrm{NMRS}\right)\end{array}$} & $\begin{array}{l}\text { Amino acids } \\
\text { and amines }\end{array}$ & - Dimethylamine & - & \multirow{3}{*}{$\begin{array}{l}\text { Non-survivors } \\
\text { in septic shock } \\
\text { had high levels } \\
\text { of 2-Hydrocyiso- } \\
\text { valerate and } \\
\text { fructose }\end{array}$} & \multirow{3}{*}{ [42] } \\
\hline & & & & & & & Fatty acids & - & $\begin{array}{l}\text { - } 2 \text {-Hydroxyiso- } \\
\text { valerate }\end{array}$ & & \\
\hline & & & & & & & Glycolysis & - & - $\quad$ Fructose & & \\
\hline \multirow{9}{*}{ 24-H mortality } & \multirow{9}{*}{$\begin{array}{l}72 \pm 0.4 \\
(30) \\
\text { vs. } \\
69 \pm 0.3 \\
(40)\end{array}$} & \multirow{9}{*}{$\begin{array}{l}12 \pm 0.6^{\$} \\
\text { vs. } \\
11 \pm 0.7^{\$}\end{array}$} & \multirow{9}{*}{$\begin{array}{l}\checkmark \\
\text { H0 and H24 of } \\
\text { vaso-pressor } \\
\text { initiation }\end{array}$} & & & \multirow{9}{*}{$\begin{array}{l}\text { Targeted } \\
\left({ }^{1} \text { H-NMRS }\right)\end{array}$} & At H0; & & & \multirow{9}{*}{$\begin{array}{l}\text { Non-surviving } \\
\text { patients with } \\
24-H \text { septic } \\
\text { shock can be } \\
\text { forecasted by } \\
\text { amino acids, } \\
\text { TCA cycle } \\
\text { metabolites, and } \\
\text { fatty acids } \\
\text { pathways }\end{array}$} & \multirow{9}{*}{ [86] } \\
\hline & & & & & & & $\begin{array}{l}\text { Amino acids } \\
\text { and amines }\end{array}$ & - & $\begin{array}{ll}\text { - } & \text { Alanine } \\
: & \text { Glutamine } \\
: & \text { Glutamate } \\
: & \text { Methionine } \\
\text { : } & \text { Phenylalanine } \\
\text { : } & \text { Lysosine } \\
\text { - } & \text { 1-Methylhistidine }\end{array}$ & & \\
\hline & & & & & & & Glycolysis & - & $\begin{array}{ll}\text { - } & \text { Pyruvate } \\
\text { - } & \text { Lactate }\end{array}$ & & \\
\hline & & & & & & & TCA cycle & - & $\begin{array}{ll}\text { - } & \text { Citrate } \\
\text { - } & \text { Fumarate }\end{array}$ & & \\
\hline & & & & & & & At H24; & & & & \\
\hline & & & & & & & $\begin{array}{l}\text { Amino acids } \\
\text { and amines }\end{array}$ & - & $\begin{array}{ll}\text { - } & \text { Tyrosine } \\
\text { - } & \text { Phenylalanine } \\
\text { - } & \text { Glutamine } \\
\text { - } & \text { Alaninate } \\
& \text { 1-Methylhistidine }\end{array}$ & & \\
\hline & & & & & & & Fatty acids & - & $\begin{array}{l}\text { - } \quad \text { 2-Hydroxyiso- } \\
\text { valerate }\end{array}$ & & \\
\hline & & & & & & & Glycolysis & - & - $\quad$ Lactate & & \\
\hline & & & & & & & TCA cycle & - & $\begin{array}{ll}\text { - } & \text { Citrate } \\
\text { - } & \text { Pyruvate }\end{array}$ & & \\
\hline
\end{tabular}


Table 4. Cont.

\begin{tabular}{|c|c|c|c|c|c|c|c|c|c|c|c|}
\hline \multirow[b]{2}{*}{ Settings } & \multirow{2}{*}{$\begin{array}{l}\text { Age (Age } \\
\text { Range) } \\
\text { (Sample Size) }\end{array}$} & \multirow{2}{*}{$\begin{array}{l}\text { APACHE-II } \\
\text { Score }\end{array}$} & \multicolumn{3}{|c|}{ Samples Since Admission } & \multirow[b]{2}{*}{ Methods } & \multicolumn{3}{|c|}{ Major Findings in Non-Survivors (NS) } & \multirow[b]{2}{*}{ Interpretation } & \multirow[b]{2}{*}{ Citation } \\
\hline & & & Serum & Plasma & Urine & & $\begin{array}{l}\text { Metabolic } \\
\text { Pathways }\end{array}$ & Decreased & Increased & & \\
\hline \multirow{8}{*}{ 24-H mortality } & \multirow{8}{*}{$\begin{array}{l}72 \pm 0.4 \\
(30) \\
\text { vs. } \\
69 \pm 0.3 \\
(40)\end{array}$} & \multirow{8}{*}{$\begin{array}{l}12 \pm 0.6^{\$} \\
\text { vs. } \\
11 \pm 0.7^{\$}\end{array}$} & \multirow{8}{*}{$\begin{array}{l}\checkmark \\
\text { H0 and H24 of } \\
\text { vaso-pressor } \\
\text { initiation }\end{array}$} & & & \multirow{8}{*}{$\begin{array}{l}\text { Targeted } \\
\left({ }^{1} \text { H-NMRS }\right)\end{array}$} & $\Delta \mathrm{H} 24-\mathrm{H} 0$ in no & vivors; & & \multirow{8}{*}{$\begin{array}{l}\text { Non-surviving } \\
\text { patients with } \\
24-H \text { septic } \\
\text { shock can be } \\
\text { forecasted by } \\
\text { amino acids, } \\
\text { TCA cycle } \\
\text { metabolites, and } \\
\text { fatty acids } \\
\text { pathways }\end{array}$} & \multirow{8}{*}{ [86] } \\
\hline & & & & & & & $\begin{array}{l}\text { Amino acids } \\
\text { and amines }\end{array}$ & - & $\begin{array}{ll}\text { - } & \text { Glutamate } \\
\text { - } & \text { Glutamine } \\
\text { - } & \text { Alanenylalanine } \\
& \text { Alanine }\end{array}$ & & \\
\hline & & & & & & & Glycolysis & - & $\begin{array}{ll}\text { - } & \text { Pyruvate } \\
\text { - } & \text { Lactate }\end{array}$ & & \\
\hline & & & & & & & TCA cycle & - & - $\quad$ Citrate & & \\
\hline & & & & & & & Others & $\begin{array}{ll}\text { - } & \text { N-Acetyl- } \\
\text { glycoprotein }\end{array}$ & - Creatinine & & \\
\hline & & & & & & & \multicolumn{3}{|c|}{$\Delta \mathrm{H} 24-\mathrm{H} 0$ in survivors; } & & \\
\hline & & & & & & & $\begin{array}{l}\text { Amino acids } \\
\text { and amines }\end{array}$ & $\begin{array}{ll}\text { - } & \text { Alanine } \\
\text { - } & \text { Plutamine } \\
\text { Phenylalanine }\end{array}$ & - & & \\
\hline & & & & & & & Glycolysis & - $\quad$ Lactate & - & & \\
\hline \multirow{5}{*}{ 7-D mortality } & \multirow{5}{*}{$\begin{array}{l}66 \pm 1 \\
(21) \\
\text { vs. } \\
64 \pm 1 \\
(29)\end{array}$} & \multirow{5}{*}{$\begin{array}{l}68 \pm 2^{\#} \\
\text { vs. } \\
54 \pm 2^{\#}\end{array}$} & \multirow{5}{*}{$\begin{array}{l}\checkmark \\
\mathrm{H} 0\end{array}$} & & & \multirow{5}{*}{$\begin{array}{l}\text { Untargeted } \\
\text { (UPLC-MS) }\end{array}$} & $\begin{array}{l}\text { Amino acids } \\
\text { and amines }\end{array}$ & $\begin{array}{ll}\bullet \quad \text { Ornithine } \\
\bullet \quad \text { Arginosuccinate } \\
\quad \text { Citrulline }\end{array}$ & $\begin{array}{ll}\bullet & \text { Proline } \\
: & \text { Valine } \\
: & \text { Leucine } \\
: & \text { Isoleucine } \\
: & \text { Glutamine } \\
: & \text { Glutamate } \\
& \text { Phenylalanine } \\
& \text { Betaine }\end{array}$ & \multirow{5}{*}{$\begin{array}{l}\text { Non-surviving } \\
\text { 7-D septic shock } \\
\text { patients } \\
\text { demonstrated } \\
\text { several precise } \\
\text { metabolomics } \\
\text { signals from } \\
\text { amino acids, } \\
\text { TCA cycle, fatty } \\
\text { acids, and } \\
\text { phosholipids } \\
\text { pathways }\end{array}$} & \multirow{5}{*}{ [87] } \\
\hline & & & & & & & Fatty acids & $\begin{array}{ll}- & \mathrm{AC} \\
& \mathrm{C} 16, \mathrm{C} 18\end{array}$ & $\begin{array}{ll}- & \mathrm{AC} \\
& \mathrm{C} 6, \mathrm{C} 10, \mathrm{C} 12\end{array}$ & & \\
\hline & & & & & & & Phospholipids & - $\quad$ LysoPE & - $\quad$ LysoPC & & \\
\hline & & & & & & & Glycolysis & - $\quad \mathrm{ACC} 2$ & - $\quad$ Lactate & & \\
\hline & & & & & & & TCA cycle & - & $\begin{array}{ll}\text { - } & \text { Succinate } \\
\text { - } & \text { Malate } \\
& \alpha \text {-ketoglutarate } \\
& \text { Citrate }\end{array}$ & & \\
\hline
\end{tabular}


Table 4. Cont.

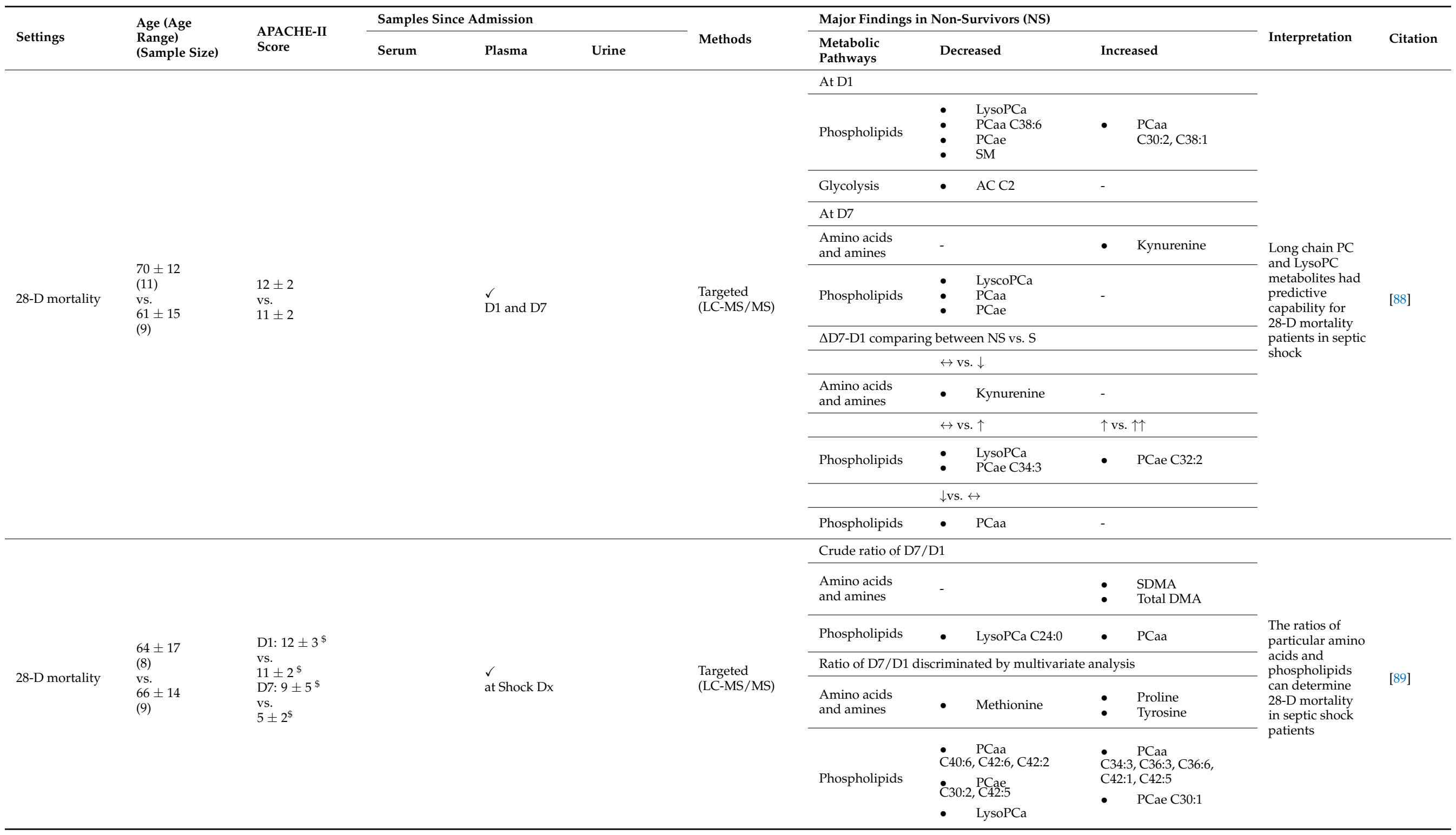


Table 4. Cont.

\begin{tabular}{|c|c|c|c|c|c|c|c|c|c|c|c|}
\hline \multirow[b]{2}{*}{ Settings } & \multirow{2}{*}{$\begin{array}{l}\text { Age (Age } \\
\text { Range) } \\
\text { (Sample Size) }\end{array}$} & \multirow{2}{*}{$\begin{array}{l}\text { APACHE-II } \\
\text { Score }\end{array}$} & \multicolumn{3}{|c|}{ Samples Since Admission } & \multirow[b]{2}{*}{ Methods } & \multicolumn{3}{|c|}{ Major Findings in Non-Survivors (NS) } & \multirow[b]{2}{*}{ Interpretation } & \multirow[b]{2}{*}{ Citation } \\
\hline & & & Serum & Plasma & Urine & & $\begin{array}{l}\text { Metabolic } \\
\text { Pathways }\end{array}$ & Decreased & Increased & & \\
\hline \multirow[t]{2}{*}{ 30-D mortality } & \multirow{2}{*}{$\begin{array}{l}65(37-79) \\
(12) \\
\text { vs. } \\
60(24-80) \\
(48)\end{array}$} & \multirow[t]{2}{*}{$\begin{array}{l}21 \pm 5 \\
\text { vs. } \\
19 \pm 6\end{array}$} & & & \multirow[t]{2}{*}{$\begin{array}{l}\checkmark \\
\text { H0 } \\
\text { and H24 }\end{array}$} & \multirow[t]{2}{*}{$\begin{array}{l}\text { Untargeted } \\
\left.\text { ( }{ }^{1} \mathrm{H}-\mathrm{NMRS}\right)\end{array}$} & $\begin{array}{l}\text { Amino acids } \\
\text { and amines }\end{array}$ & $\begin{array}{ll}\text { - } & \text { Methionine } \\
& \text { Glutamine } \\
\text { Arginine } \\
\quad & \text { Phenylalanine } \\
\end{array}$ & - & \multirow{2}{*}{$\begin{array}{l}\text { Particular amino } \\
\text { acids, glycolytic } \\
\text { metabolites, and } \\
\text { alcohol can } \\
\text { predict } 30-\mathrm{D} \\
\text { mortality in } \\
\text { septic shock } \\
\text { patients }\end{array}$} & \multirow[t]{2}{*}{ [90] } \\
\hline & & & & & & & Glycolysis & - & - $\quad$ Glucose & & \\
\hline \multirow{10}{*}{ 90-D mortality } & \multirow{10}{*}{$\begin{array}{l}70 \pm 12 \\
(24) \\
\text { vs. } \\
61 \pm 15 \\
(9)\end{array}$} & \multirow{10}{*}{$\begin{array}{l}12 \pm 2 \\
\text { vs. } \\
11 \pm 2\end{array}$} & & \multirow{10}{*}{$\begin{array}{l}\checkmark \\
\text { D1 and D7 }\end{array}$} & & \multirow{10}{*}{$\begin{array}{l}\text { Targeted } \\
\text { (LC-MS/MS) }\end{array}$} & \multicolumn{3}{|l|}{ At D1 } & \multirow{10}{*}{$\begin{array}{l}\text { Long chain PC } \\
\text { and LysoPC } \\
\text { metabolites had } \\
\text { predictive } \\
\text { capability for } \\
90-D \text { mortality in } \\
\text { septic shock } \\
\text { patients }\end{array}$} & \multirow{10}{*}{ [88] } \\
\hline & & & & & & & Phospholipids & $\begin{array}{l}\text { - } \quad \text { PCaa } \\
\quad \text { C36:6, C38:4, C38:6 }\end{array}$ & - & & \\
\hline & & & & & & & \multicolumn{3}{|l|}{ At D7 } & & \\
\hline & & & & & & & Phospholipids & $\begin{array}{ll}\text { - } & \text { LysoPCa } \\
& \text { C16:0, C16:1, } \\
\text { C18:0 } \\
\text { - } & \text { PCaa } \\
\text { - } & \text { PCae }\end{array}$ & \multirow[t]{3}{*}{ - $\quad$ LysoPCa C24:0 } & & \\
\hline & & & & & & & \multirow{2}{*}{\multicolumn{2}{|c|}{$\begin{array}{c}\Delta \text { D7-D1 comparing between NS vs. } S \\
\leftrightarrow \text { vs. } \downarrow\end{array}$}} & & & \\
\hline & & & & & & & & & & & \\
\hline & & & & & & & \multicolumn{2}{|r|}{$\leftrightarrow$ vs. $\uparrow$} & $\uparrow$ vs. $\uparrow \uparrow$ & & \\
\hline & & & & & & & Phospholipids & $\begin{array}{ll}\text { - } & \text { LysoPCa } \\
\text { - } & \text { PCaa C } 32: 3\end{array}$ & $\begin{array}{l}-\quad \text { PCaa C34:3, C34:4 } \\
\quad \text { PCae C32:2 }\end{array}$ & & \\
\hline & & & & & & & & $\leftrightarrow(\downarrow)$ vs. $\leftrightarrow(\uparrow)$ & & & \\
\hline & & & & & & & Phospholipids & - $\quad$ PCaa C38:1 & - & & \\
\hline \multirow[t]{2}{*}{ 1-Y mortality } & \multirow{2}{*}{$\begin{array}{l}69(61-77) \\
(4) \\
\text { vs. } \\
58(50-65) \\
(7)\end{array}$} & \multirow[t]{2}{*}{$\begin{array}{l}15(14-17)^{\$} \\
\text { vs. } \\
14(9-14)^{\$}\end{array}$} & \multirow{2}{*}{$\begin{array}{l}\checkmark \\
\text { H0, H24, and } \\
\text { H48 after } \\
\text { L-carnitine } \\
\text { infusion }\end{array}$} & & & $\begin{array}{l}\text { Untargeted } \\
\text { (LC-MS) }\end{array}$ & $\begin{array}{l}\text { Amino acids } \\
\text { and amines }\end{array}$ & $\begin{array}{ll}\text { - } & \text { N-acetyl-L- } \\
\text { phenylalanine } \\
\text { - Phenylalanyl- } \\
\text { tyrosine }\end{array}$ & $\begin{array}{ll}\text { - } & N \text {-methyl-phenyl- } \\
& \text { alanine } \\
\text { - } \quad & \text { Isoleucyl-proline } \\
\text { - Leucyl-proline }\end{array}$ & $\begin{array}{l}\text { 1-Y mortality in } \\
\text { septic shock } \\
\text { patients can be } \\
\text { determined by } \\
\text { certain amino } \\
\text { acids, fatty acids, }\end{array}$ & [91] \\
\hline & & & & & & & Fatty acids & - & $\begin{array}{l}\text { Adipoyl-L- } \\
\text { carnitine }\end{array}$ & $\begin{array}{l}\text { and } \\
\text { peptide/short } \\
\text { chain proteins }\end{array}$ & \\
\hline
\end{tabular}

Continuous data are presented in mean \pm SD, otherwise reported as median and IQR1-3. ${ }^{\$}$ Sequential Organ Failure Assessment (SOFA) score. ${ }^{\#}$ Simplified Acute Physiology score 2 SAPS2) * overall information. Abbreviations: ${ }^{1} \mathrm{H}-\mathrm{NMRS},{ }^{1} \mathrm{H}-$-Nuclear Magnetic Resonance Spectroscopy; a, acyl; aa, diacyl; ae, acyl-akyl; APACHE-II score, Acute Physiology and Chronic Health Evaluation-II score; C, number of carbons in the fatty acid side chain; D, Day; DMA, Dimethylarginine; GCA, Glycocholic acid; GCDCA, Glycochenodeoxycholic acid; GUDCA, Glycoursodeoxycholic acid; GUDCS, 3-glycine chenodeoxycholic acid; H, Hour; LC-MS, liquid chromatography-mass spectrometry; LC-MS/MS, liquid chromatography-tandem mass spectrometry; LysoPC, lysophosphatidylcholine; LysoPE, Lysophosphatidylethanolamine; NS, Non-survivor; S, Survivor; SDMA, Symmetric dimethylarginine; SM, Sphingomyelin; TCA cycle, tricarboxylic acid cycle; UDCA, Ursodeoxycholic acid; UPLC-MS, Ultra-performance liquid chromatography-mass spectrometry; Y, Year. 


\subsection{Alterations of Amino Acids and Amines in Septic Shock Non-Survivors}

Dimethylamine [42] and citrulline [87] and were observed decreasing in septic shock non-survivors. In contrast, SDMA [89], total DMA [89], and tyrosine [89], were increased in septic shock patients with non-survival. Interestingly, the discrepancy regarding phenylalanine $[86,87,91]$ and methionine $[86,87,90,91]$ were revealed among studies.

\subsubsection{A Decrease in Dimethylamine and Citrulline}

One study revealed a decreased level of dimethylamine in septic shock non-survivors [42]. Dimethylamine is originated from fish and seafood consumption and it is a byproduct of the post-translation modification of arginine that involved in the inhibition of NO synthesis [76,92]. Therefore, future research might be conducted to identify the benefit of dimethylamine supplementation in septic shock patients.

Another study reported that a decrement of citrulline at baseline could predict septic shock non-survivors at day 7 [87]. This low level of citrulline is likely due to a decrease in citrulline absorption through the gastrointestinal tract [49]. Or it might be related to a low level of ornithine and arginosuccinate [87], which involved in citrulline metabolism in the urea cycle pathway. These results suggested that the disturbance of urea cycle can be a potential indicator of septic shock with non-survival.

6.1.2. An Increase in Symmetric Dimethylarginine, Total Dimethylarginine, and Tyrosine

A prior study revealed that SDMA and total DMA, competitive inhibitors of NO synthesis, were increased in septic shock non-survivors at day 28 [89]. Hence, measuring these metabolites could be used prognosticating the patients with septic shock outcomes.

Tyrosine is a precursor for catecholamine biosynthesis under the activity of specific enzyme-phenylalanine hydroxylase (PAH) $[16,55]$. Two studies demonstrating an increase in tyrosine level as a predictor of the septic shock non-survivors at $24 \mathrm{~h}$ after ICU admission [86] and at day 28, respectively [89]. This phenomena might be explained by the fact that PAH function is impaired during sepsis [55].

\subsubsection{An Alternation of Phenylalanine and Methionine}

The alternation of phenylalanine in septic shock non-survivors were controversial. Indeed, previous studies revealed a decreased phenylalanine in septic shock non-survivors at day 30 [90] and at one year [91]. On the contrary, other studies showed an increased phenylalanine in the non-survivors at $24 \mathrm{~h} \mathrm{[86]} \mathrm{and} \mathrm{at} \mathrm{day} 7$ [87]. Since phenylalanine and tyrosine are involved in the same pathway, a whole pathway study may be further investigated in order to justify how phenylalanine interacts in septic shock non-survivors.

Methionine, one of the sulfur-containing amino acids, is a precursor for the syntheses of homocysteine, cysteine, glutathione, creatine, and polyamines [93]. A prior study displayed a decrease in methionine in non-surviving patients with septic shock at day 30 [90]. Furthermore, a decrease in methionine day $7 /$ day 1 ratio in sepsis non-survivors at day 28 were observed [89]. However, one study demonstrated an increased level of methionine in septic shock non-survivors at $24 \mathrm{~h}$ [86]. Therefore, a future study quantifying the levels of methionine and its related metabolites should be conducted in order to clarify the inconsistent findings of methionine among studies.

\subsection{Alterations of Fatty Acid-Related Metabolites in Septic Shock Non-Survivors}

In non-surviving patients with septic shock at day 7, the level of long-chain ACs, including C16 and C18 carnitines, were decreased [87]. On the contrary, the level of medium-chain ACs, including C6, C10, and C12 carnitines, were increased [87]. These results indicating a decrease in FA uptake into the mitochondria and incomplete $\beta$-oxidation of long-chain FAs, which can be one of the potential markers of septic shock mortality. 


\subsection{Alterations of Phospholipids in Septic Shock Non-Survivors}

Several phospholipids were involved in patients with septic shock non-survivors. A reduction in C18:0, C18:2, C20:4, and C20:5 lysophosphatidylethanolamines (lysoPEs) were found in septic shock non-survivors at day 7 [87]. LysoPE is a minor component of the cell membrane lysophospholipids where physiological significance remains undetermined [94]. In addition, a decrease in lysoPCa C16:0, C18:0, and C24:0 was also displayed in septic shock non-survivors at day 28 [88]. However, an increase in C14:0 and C24:0 lysoPCs was reported in other studies $[87,88]$.

Two studies discovered an alternation of several PCs in septic shock non-survivors $[88,89]$. The non-survivors at day 28 had a decrease in PCaa C32:3, PCaa C34:4, PCaa C36:4, PCae C34:3, and PCae C42:4 [88], and a ration from day 7 by day 1 of PCaa C40:6, PCaa C42:6, PCaa C42:2, PCae C32:2, and PCae C42:5 [89]. Furthermore, some of these PCs had been decreased in the non-survivors at day 90 as well [89]. However, the latest study mentioned an increment in PCae C30:1 in the non-survivors [89]. These findings suggest that several PCs can be used as prognosticating biomarkers for septic shock patients.

\subsection{Alterations of Glycolysis-Related Metabolites and TCA Cycle Metabolites in Septic Shock Non-Survivors}

Hyperglycemia is commonly present in sepsis to provide sufficient glucose for neurons and leucocytes [30]. Glucose was found to be increased in patients with septic shock nonsurvivors at day 30 [90]. However, hypoglycemia can also be detected in sepsis and is associated with a lethal outcome as well [32].

Lactate was found to be increased in septic shock non-survivors within $24 \mathrm{~h} \mathrm{[86]} \mathrm{and}$ at day 7 [87]. Moreover, pyruvate was also increased in the non-survivors at day 7 [87]. Acetylcarnitine ( $\mathrm{C} 2$ carnitine) was decreased in patients with septic shock non-survivors at day 7 [87]. This finding is in contrast to that mentioned in Section 4.2, where septic shock patients had an increased acetylcarnitine compared to the non-septic shock patients [23,42]. These contradictory results may be explained by a failure of the metabolic flexibility of acetylcarnitine to switch as fuel sources during sepsis [28].

As a result of mitochondrial dysfunction in sepsis [95], multiple TCA cycle metabolites including citrate, $\alpha$-ketoglutarate, succinate, fumarate, and malate were increased in septic shock non-survivors within $24 \mathrm{~h}$ and at day $7[86,87]$. These metabolites represent an augmentation of aerobic metabolism during sepsis, which promotes oxidative phosphorylation and releases of reactive oxygen species (ROS) $[96,97]$. The ROS may be one of several reasons for sepsis-induced mitochondrial dysfunction [98].

\section{Metabolomics for Monitoring Treatment Response in Sepsis and Septic Shock}

Two studies have revealed metabolomics that monitor the treatment response in sepsis population $[99,100]$. The first study aimed to identify patients who would reduce the use of vasopressor after L-carnitine supplementation using metabolomics study [99]. A good response was found in patients with a low ketotic state (3-hydroxybutyrate $<153 \mu \mathrm{M}$ ), where methionine, lysine, phenylalanine, and tyrosine were found to be increased after L-carnitine was given [99]. In addition, patients with a good response had a low level of carnitine and acetylcarnitine as well [99]. The second study characterized septic shock patients who had a sequential organ failure assessment (SOFA) score of lower than 8 or a drop of more than 5 within $48 \mathrm{~h}$ after treatment [100]. An untargeted metabolomics comparing the degree of metabolites changes between the responders and non-responders overtime (from baseline to $48 \mathrm{~h}$ ) found that myristic acid and oleic acid were more decreased, whereas creatinine was less decreased in the responders than that of the non-responders [100]. From targeted metabolomics, alterations of several metabolites showed differently. When comparing the degree of metabolites changes overtime, kynurenine was increased in the responders but lower than of the non-responders. Interestingly, several phospholipids had a predictive ability to determine treatment response. Indeed, most $\mathrm{SMs}, \mathrm{SM}(\mathrm{OH}) \mathrm{s}$, and PCs were increased in the responders, whereas they were decreased in the non-responders. In addition, 
SM C16:1 and C16-C20 lysoPCs were both increased in both groups; however, a greater increment was found in the responders than in the non-responders [100]. These findings suggest that several metabolites can be potential markers for monitoring the treatment response in sepsis patients.

\section{Conclusions}

Metabolomics is about to change the world of sepsis biomarkers. Not only can it be utilized for sepsis diagnosis, but also for prognosticating and monitoring the therapeutic response. In this review, we found that sepsis can lead to the alteration of enormous metabolites.

Some significant amino acids, according to the study populations, are summarized in Figure 1. Multiple amino acids can be used as operational markers for sepsis determination, for instance, arginine, proline, and kynurenine, whereas BCAAs can be used as predictive markers to identify patient survival.

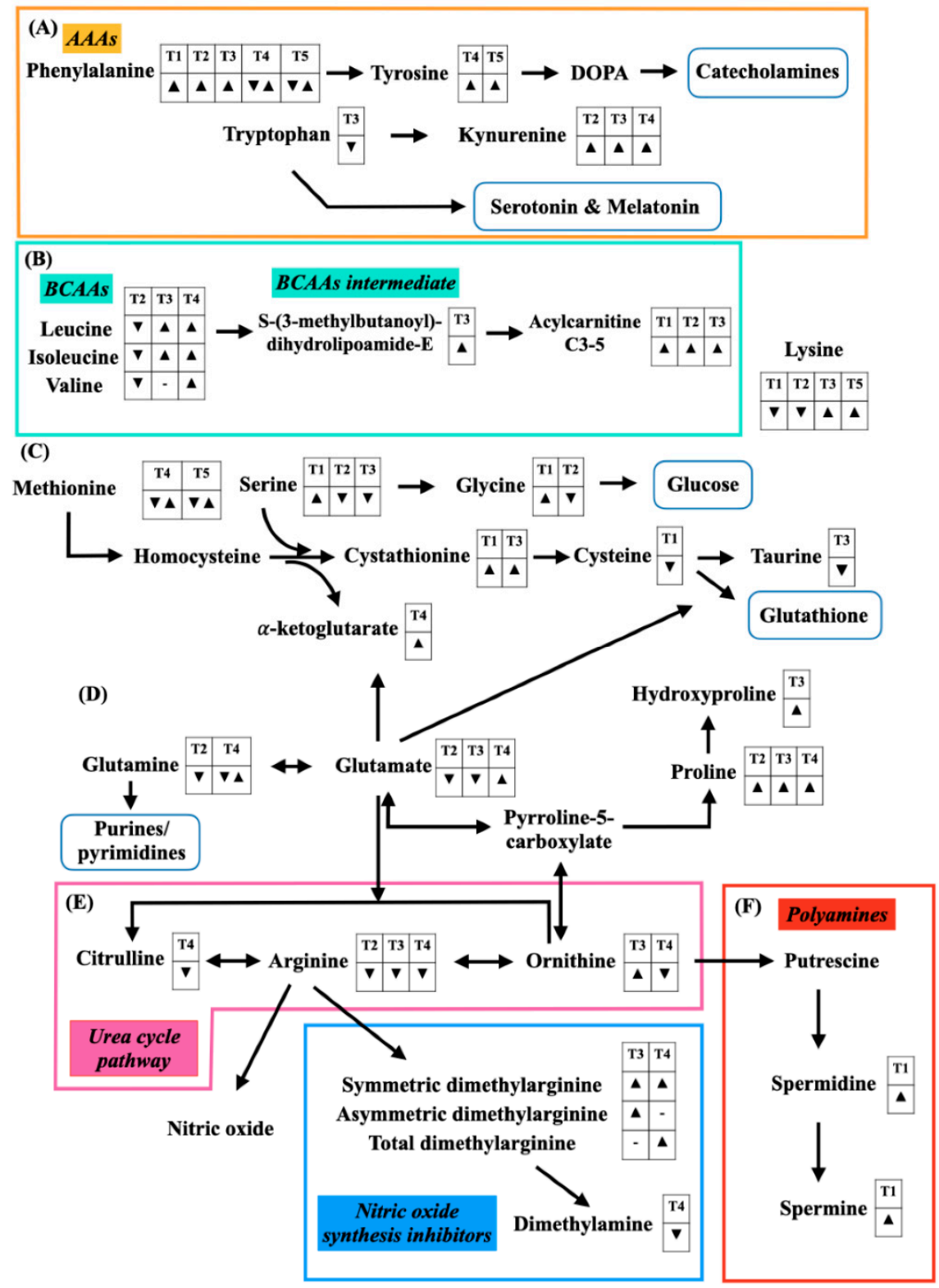

Figure 1. Alterations of amino acids and amines for sepsis diagnosis (Table 1), septic shock diagnosis 
(Table 2), prognostication of sepsis (Table 3), prognostication of septic shock (Table 4), and monitoring the treatment response (Table 5). A down-sided triangle ( $\mathbf{\nabla})$ represents a decreased level, whereas an up-sided triangle $(\mathbf{\Lambda})$ represents vice versa. (A) Aromatic amino acids (AAAs) and its down-stream amino acid are illustrated. Phenylalanine is converted to tyrosine before metabolizing to dihydroxyphenylalanine (DOPA) and catecholamines, respectively. Tryptophan is another AAA that can change to either kynurenine or serotonin and melatonin. (B) Branched-chain amino acids (BCAAs) including leucine, isoleucine, and valine are catabolized to $S$-(3-methylbutanoyl)-dihydrolipoamide-E and amino acid-derived acylcarnitines (C3-5), respectively. (C) A substrate of glutathione synthesis begins with methionine that converts into homocysteine, cystathionine, and cysteine, respectively. Moreover, serine is involved in the cystathionine production with an exchange of $\alpha$-ketoglutarate. Cysteine can also turn into taurine, which has an anti-oxidant effect. (D) Glutamate is an intermediate substrate between glutathione production and urea cycle-related metabolites. Glutamate can be converted into glutamine and pyrroline-5-carboxylate (P5C). The latter metabolite is a precursor for proline synthesis. Moreover, glutamate can interchange with the urea cycle pathway metabolites. (E) The urea cycle pathway metabolites included citrulline, arginine, and ornithine. Arginine is a key amino acid for nitric oxide (NO) synthesis and NO inhibitors, including symmetric dimethylarginine (SMDA), asymmetric dimethylarginine (ADMA), total dimethylarginine (total DMA), and dimethylamine. (F) Polyamines are converted from ornithine. The polyamine metabolites include putrescine, spermidine, and spermine.

Free FAs are summarized in Figure 2. These metabolites also present as sepsis biomarkers as well; however, a further study combining FAs with other connecting metabolic pathways, in particular FA-derived ACs and TCA cycle metabolites, with a step-by-step metabolomic approach in each of these pathways, is needed.

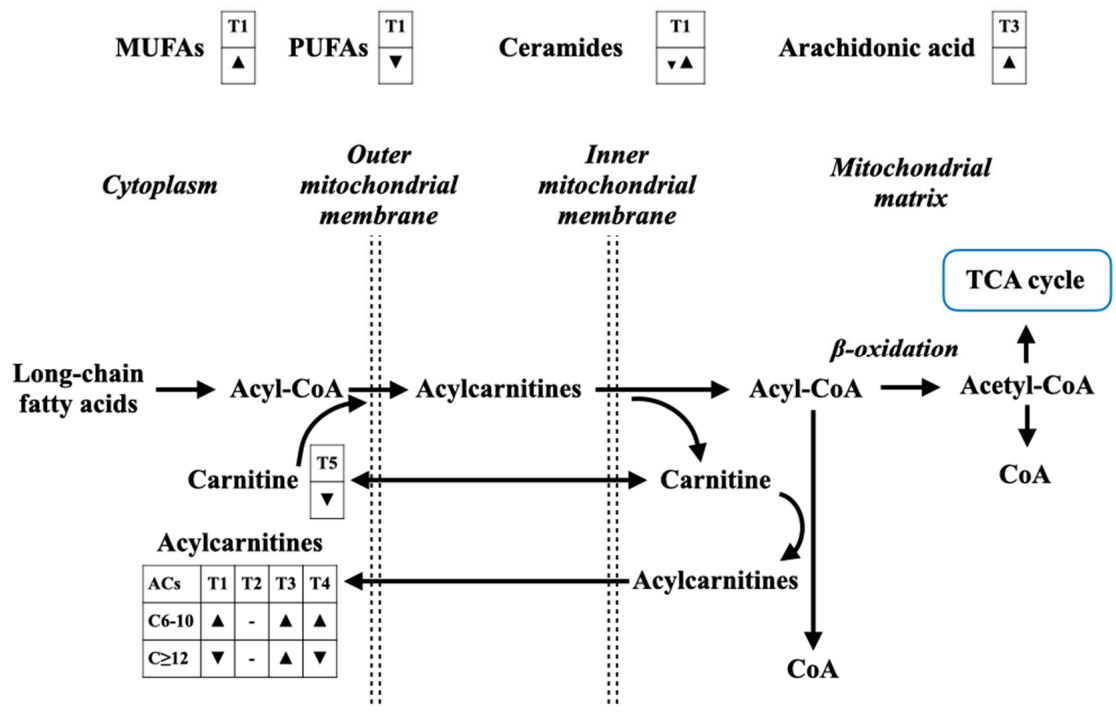

Figure 2. The alterations of fatty acids and fatty acid-related metabolites for sepsis diagnosis (Table 1), septic shock diagnosis (Table 2), prognostication of sepsis (Table 3), prognostication of septic shock (Table 4), and monitoring the treatment response (Table 5). A down-sided triangle ( $\mathbf{\nabla})$ represents a decreased level, whereas an up-sided triangle $(\boldsymbol{\Lambda})$ represents vice versa. Monounsaturated fatty acids (MUFAs) are found increased in sepsis diagnosis, whereas polyunsaturated fatty acids (PUFAs) are found contractedly. Most of ceramides are increased, together with an increase in arachidonic acids. Long-chain fatty acids enter mitochondrial for fatty acid oxidation ( $\beta$-oxidation) under the carnitine shuttle process. The final product of $\beta$-oxidation is acetyl-CoA that can enter TCA cycle for an energy production. However, mitochondrial dysfunction in sepsis can alter $\beta$-oxidation process, leading to an accumulation of medium-chain acylcarnitines in the cytoplasm and in the circulation, which indicates incomplete $\beta$-oxidation. 
Table 5. Metabolomics-assisted treatment monitoring in patients with sepsis/septic shock.

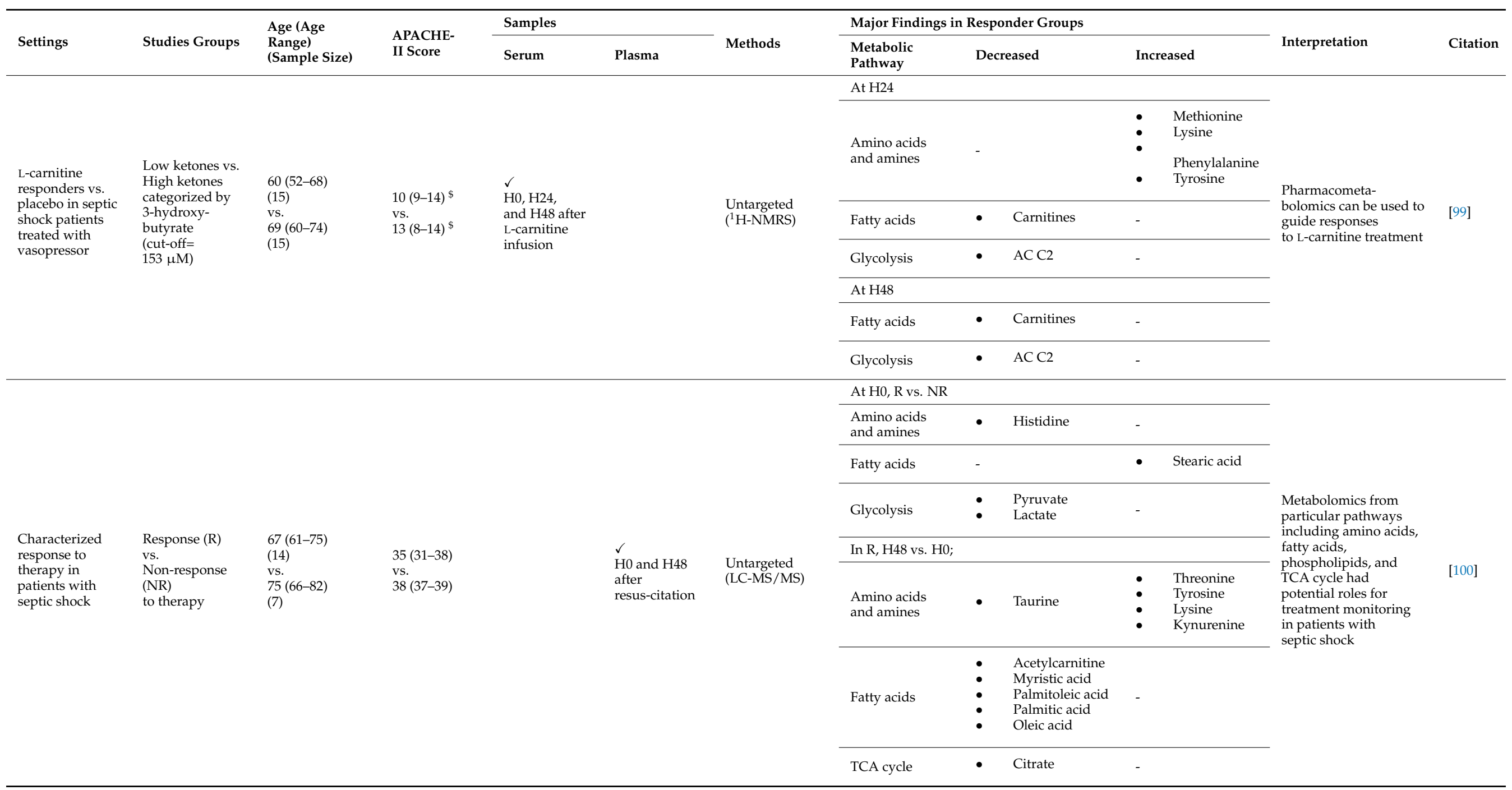


Table 5. Cont.

\begin{tabular}{|c|c|c|c|c|c|c|c|c|c|c|c|}
\hline \multirow[b]{2}{*}{ Settings } & \multirow[b]{2}{*}{ Studies Groups } & \multirow{2}{*}{$\begin{array}{l}\text { Age (Age } \\
\text { Range) } \\
\text { (Sample Size) }\end{array}$} & \multirow{2}{*}{$\begin{array}{l}\text { APACHE- } \\
\text { II Score }\end{array}$} & \multicolumn{2}{|c|}{ Samples } & \multirow[b]{2}{*}{ Methods } & \multicolumn{3}{|c|}{ Major Findings in Responder Groups } & \multirow[b]{2}{*}{ Interpretation } & \multirow[b]{2}{*}{ Citation } \\
\hline & & & & Serum & Plasma & & $\begin{array}{l}\text { Metabolic } \\
\text { Pathway }\end{array}$ & Decreased & Increased & & \\
\hline \multirow{10}{*}{$\begin{array}{l}\text { Characterized } \\
\text { response to } \\
\text { therapy in } \\
\text { patients with } \\
\text { septic shock }\end{array}$} & \multirow{6}{*}{$\begin{array}{l}\text { Response (R) } \\
\text { vs. } \\
\text { Non-response } \\
\text { (NR) } \\
\text { to therapy }\end{array}$} & \multirow{6}{*}{$\begin{array}{l}67(61-75) \\
(14) \\
\text { vs. } \\
75(66-82) \\
(7)\end{array}$} & \multirow{6}{*}{$\begin{array}{l}35(31-38) \\
\text { vs. } \\
38(37-39)\end{array}$} & & \multirow{6}{*}{$\begin{array}{l}\checkmark \\
\text { H0 and H48 } \\
\text { after } \\
\text { resus-citation }\end{array}$} & \multirow{6}{*}{$\begin{array}{l}\text { Untargeted } \\
\text { (LC-MS/MS) }\end{array}$} & In NR, H48 vs. & & & \multirow{6}{*}{$\begin{array}{l}\text { Metabolomics from } \\
\text { particular pathways } \\
\text { including amino acids, } \\
\text { fatty acids, } \\
\text { phospholipids, and } \\
\text { TCA cycle had } \\
\text { potential roles for } \\
\text { treatment monitoring } \\
\text { in patients with } \\
\text { septic shock }\end{array}$} & \multirow{6}{*}{ [100] } \\
\hline & & & & & & & $\begin{array}{l}\text { Amino acids } \\
\text { and amines }\end{array}$ & - & $\begin{array}{ll}\text { - } & \text { Threonine } \\
\text { - } & \text { Arginine } \\
\text { Lysine }\end{array}$ & & \\
\hline & & & & & & & Fatty acids & $\begin{array}{ll}- & \text { Acetylcarnitine } \\
- & \text { Stearic acid } \\
- & \text { Myristic acid } \\
- & \text { Palmitoleic acid } \\
- & \text { Palmitic acid } \\
- & \text { Oleic acid }\end{array}$ & - & & \\
\hline & & & & & & & \multicolumn{3}{|c|}{ Comparing R vs. NR overtime } & & \\
\hline & & & & & & & \multicolumn{2}{|r|}{$\downarrow$ vs. $\downarrow \downarrow$} & $\downarrow$ vs. $\uparrow$ & & \\
\hline & & & & & & & Fatty acids & $\begin{array}{ll}\text { - } & \text { Myristic acid } \\
\text { Oleic acid }\end{array}$ & & & \\
\hline & & & & & & \multirow{4}{*}{$\begin{array}{l}\text { Targeted } \\
\text { (LC-MS) }\end{array}$} & \multicolumn{3}{|c|}{ In R, H48 vs. H0; } & & \\
\hline & & & & & & & Phospholipids & - & $\begin{array}{ll}\text { - } & \text { SM } \\
\bullet & \text { LysoPCa } \\
\bullet & \text { PCaa } \\
& \text { PCae }\end{array}$ & & \\
\hline & & & & & & & \multicolumn{3}{|c|}{ In NR, $\mathrm{H} 48$ vs. H0; } & & \\
\hline & & & & & & & $\begin{array}{l}\text { Amino acids } \\
\text { and amines }\end{array}$ & - $\quad$ Taurine & $\begin{array}{ll}\bullet & \text { Arginine } \\
: & \text { Lysine } \\
: & \text { Ornithine } \\
: & \text { Serine } \\
: & \text { Threonine } \\
: & \text { Tryptophan } \\
- & \text { Kynurenine }\end{array}$ & & \\
\hline
\end{tabular}


Table 5. Cont.

\begin{tabular}{|c|c|c|c|c|c|c|c|c|c|c|c|}
\hline \multirow[b]{2}{*}{ Settings } & \multirow[b]{2}{*}{ Studies Groups } & \multirow{2}{*}{$\begin{array}{l}\text { Age (Age } \\
\text { Range) } \\
\text { (Sample Size) }\end{array}$} & \multirow[b]{2}{*}{$\begin{array}{l}\text { APACHE- } \\
\text { II Score }\end{array}$} & \multicolumn{2}{|c|}{ Samples } & \multirow[b]{2}{*}{ Methods } & \multicolumn{3}{|c|}{ Major Findings in Responder Groups } & \multirow[b]{2}{*}{ Interpretation } & \multirow[b]{2}{*}{ Citation } \\
\hline & & & & Serum & Plasma & & $\begin{array}{l}\text { Metabolic } \\
\text { Pathway }\end{array}$ & Decreased & Increased & & \\
\hline & & & & & & & Phospholipids & $\begin{array}{ll}\text { - } & \mathrm{SM}(\mathrm{OH}) \mathrm{C} 24: 1 \\
\bullet & \mathrm{PCaa} \\
& \text { PCae }\end{array}$ & - $\quad$ LysoPCa & & \\
\hline & & & & & & & Comparing R vs. & R overtime; & & & \\
\hline & & & & & & & & $\uparrow$ vs. $\uparrow \uparrow$ & & & \\
\hline & & & & & & & & $\uparrow$ vs. $\downarrow$ & $\uparrow \uparrow$ vs. $\uparrow$ & & \\
\hline & & & & & & & Phospholipids & $\begin{array}{ll}\text { - } & \text { SM } \\
& \text { C16:0, C18:0, } \\
& \text { C18:1 } \\
\text { - } & \text { SM(OH) C24:1 } \\
\bullet & \text { PCaa } \\
- & \text { PCae }\end{array}$ & $\begin{array}{ll}\bullet & \text { SM C16:1 } \\
- & \text { LysoPCa }\end{array}$ & & \\
\hline & & & & & & & At $\mathrm{H} 48, \mathrm{R}$ vs. NR & & & & \\
\hline & & & & & & & Phospholipids & - & $\begin{array}{ll}\text { - } & \text { SM } \\
\text { - } & \text { LysoPCa } \\
\text { PCae }\end{array}$ & & \\
\hline
\end{tabular}

Continuous data are presented as median and IQR1-3. \$ Sequential Organ Failure Assessment (SOFA) score; a, acyl; aa, diacyl; ae, acyl-akyl; APACHE-II score, Acute Physiology and Chronic Health Evaluation-II score; C, number of carbons in the fatty acid side chain; H, Hour, LC-MS, liquid chromatography-mass spectrometry; LC-MS/MS, liquid chromatographytandem mass spectrometry; LysoPC, lysophosphatidylcholine; NR, Non-responder; PC, phosphatidylcholine; R, Responder; SM, Sphingomyelin; TCA cycle, tricarboxylic acid cycle. 
Figure 3 demonstrates phospholipid-related membrane phospholipids, as sepsis always interferes in this structure. For this reason, any interventions that can specifically protect the cell membrane injury by septic pathogens may be established under the guide of the levels of these metabolites.

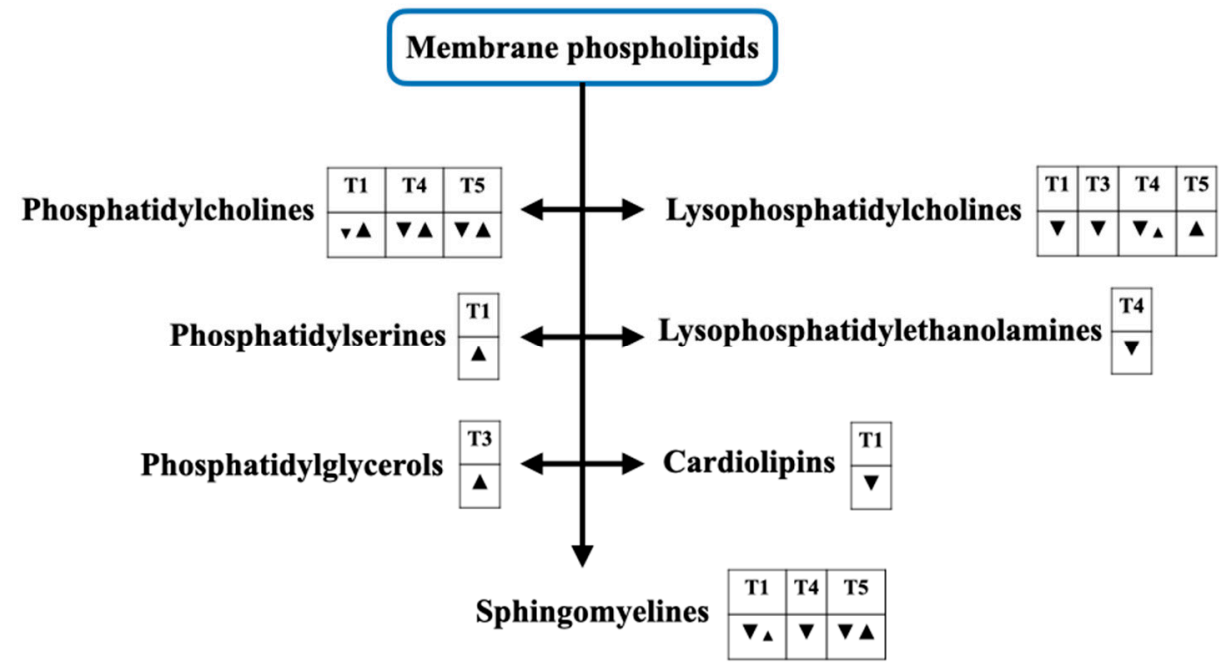

Figure 3. (Previous page) The alterations of cell membrane phospholipids for sepsis diagnosis (Table 1), septic shock diagnosis (Table 2), prognostication of sepsis (Table 3), prognostication of septic shock (Table 4), and monitoring the treatment response (Table 5). A down-sided triangle ( $\mathbf{\nabla})$ represents a decreased level, whereas an up-sided triangle $(\boldsymbol{\Delta})$ represents vice versa. Several kinds of the cell membrane phospholipids are involved in this setting. An alteration of phosphatidylcholines (PCs), phosphatidylserine (PS), phosphatidylglycerols (PGs), lysophosphatidylcholines (LysoPCs), lysophosphatidylethanolamines (LysoPEs), cardiolipins, and sphingomyelines (SMs) are demonstrated.

Besides hemodynamic resuscitation in sepsis patients, mitochondrial resuscitation remains another issue for treatment response monitoring [101]. Although lactate is a commonly accepted use for the monitoring of tissue perfusion, the alternations of mitochondrial TCA cycle metabolites may also be used in mitochondrial resuscitation as well. A complete understanding of whole glycolysis and TCA cycle metabolites, as in Figure 4, could be well-achieved by metabolomics study.

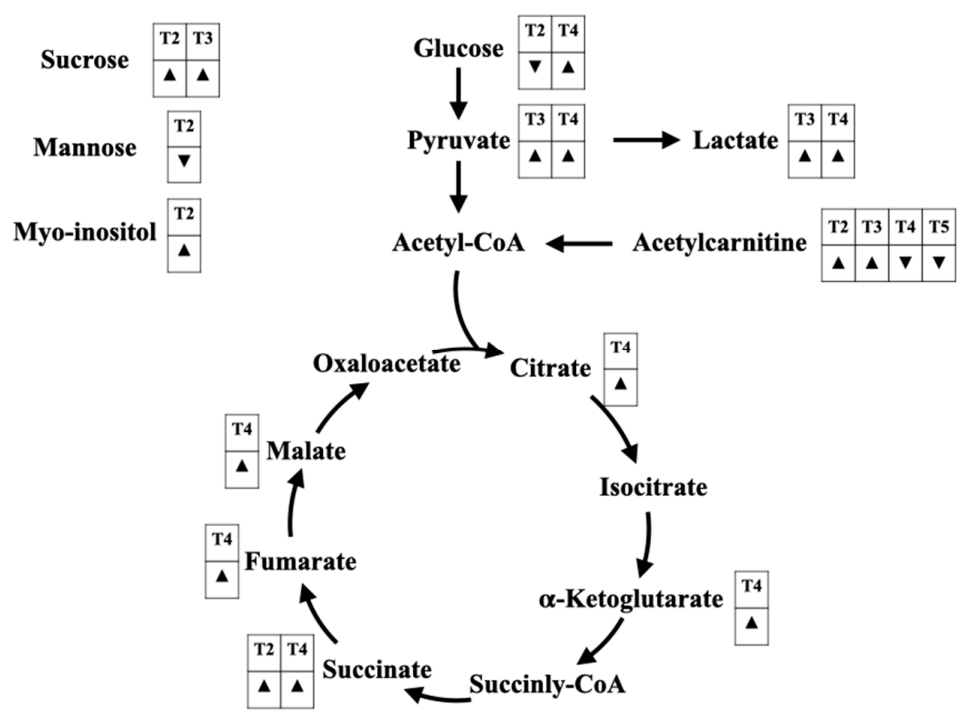

Figure 4. The alterations of glycolysis-related metabolites and tricarboxylic acid (TCA) cycle metabolites 
for sepsis diagnosis (Table 1), septic shock diagnosis (Table 2), prognostication of sepsis (Table 3), prognostication of septic shock (Table 4), and monitoring the treatment response (Table 5). A downsided triangle $(\boldsymbol{\nabla})$ represents a decreased level, whereas an up-sided triangle $(\boldsymbol{\Lambda})$ represents the opposite. The alterations of several sugars are found, including glucose, sucrose, mannose, and myo-inositol. Glucose, a main energy source for human cells, converts to pyruvate and acetyl-CoA, respectively, before entering the TCA cycle. In addition, acetylcarnitine (C2 carnitine) can feed via acetyl-CoA as well. Another anaerobic metabolite, lactate, are found to be increased in sepsis patients with poor prognosis. Citrate is the initial metabolite of the TCA cycle, which turns into isocitrate, $\alpha$-ketoglutarate, succinyl-CoA, succinate, fumarate, malate, and oxaloacetate, respectively. The increases in TCA cycle-related metabolites represent an augmentation of aerobic metabolism during sepsis, which can promote oxidative phosphorylation and reactive oxygen species (ROS) production. An increase in the ROS level may be one of the potential mechanisms mediating sepsis-induced mitochondrial dysfunction.

\section{Limitation and Future Direction of the Metabolomic Research in Sepsis}

The current advanced technology of metabolomics is just shinning the light at the beginning of the tunnel in terms of providing more precise biomarkers for sepsis. An uncertain standardization of the metabolomic studies is one of the major issues for replicating the results. Moreover, the complexity and heterogeneity of sepsis create are a large variety of study populations. Therefore, a combination of conventional biomarkers and metabolomic profiling is likely a key solution. Moreover, multi-omics modalities and systems of biology should be simultaneously approached, since sepsis is also associated with the alterations of protein and gene expression [102,103].

According to septic shock resuscitation, besides the bed-sided hemodynamic monitoring, metabolic and cellular resuscitation are crucial strategic keys to improve patient outcomes. Currently, no definite metabolic abnormality is warranted beyond hyperlactatemia [1]. We highly expect that metabolomics can be one of the solutions used to examine mitochondrial function or even abnormalities of the microcirculation in sepsis. Future studies with the metabolomics approach, attempting to develop bedside laboratory kits, are incredibly significant for the clinical practice.

Metabolomics to foresee outcomes of patients with sepsis and septic shock are undergoing research. Death signaling metabolites' modulation is another remedy to improve patients' outcomes. The integral application of pharmacometabolomics to identify the appropriate drugs or to certify suitable, well-responsive patients is another approach for precision medicine.

Nowadays, a lot of information about metabolites in sepsis comes across without enough pathophysiological elucidation. Moreover, the overwhelming evidence of metabolomic information in sepsis is challenging. Therefore, artificial intelligence facilitating machine learning experiences may be a worthwhile solution to handle this enormous information. In the end, we believe that metabolomics can illuminate the light at the end of the tunnel of sepsis management.

Author Contributions: Conceptualization, K.T., C.T., C.P., S.C.C. and N.C.; data curation, K.T. and C.T.; writing - original draft preparation, K.T. and C.T.; writing-review and editing, N.C.; visualization, K.T.; supervision, C.P., S.C.C. and N.C. All authors have read and agreed to the published version of the manuscript.

Funding: This study was supported by a Research grant for a New Scholar from the National Research Council of Thailand (C.T.), a Senior Research Scholar grant from the National Research Council of Thailand (S.C.C.), the NSTDA Research Chair Grant from the National Science and Technology Development Agency Thailand (N.C.), and a Chiang Mai University Center of Excellence Award (N.C.). 
Conflicts of Interest: The authors declare no conflict of interest. The funders had no role in the design of the study; in the collection, analyses, or interpretation of data; in the writing of the manuscript, or in the decision to publish the results.

\section{References}

1. Singer, M.; Deutschman, C.S.; Seymour, C.W.; Shankar-Hari, M.; Annane, D.; Bauer, M.; Bellomo, R.; Bernard, G.R.; Chiche, J.-D.; Coopersmith, C.M.; et al. The Third International Consensus Definitions for Sepsis and Septic Shock (Sepsis-3). JAMA 2016, 315, 801-810. [CrossRef]

2. Vincent, J.-L.; Marshall, J.C.; A Namendys-Silva, S.A.; François, B.; Martin-Loeches, I.; Lipman, J.; Reinhart, K.; Antonelli, M.; Pickkers, P.; Njimi, H.; et al. Assessment of the worldwide burden of critical illness: The Intensive Care Over Nations (ICON) audit. Lancet Respir. Med. 2014, 2, 380-386. [CrossRef]

3. Levy, M.M.; Evans, L.E.; Rhodes, A. The Surviving Sepsis Campaign Bundle: 2018 update. Intensiv. Care Med. 2018, 44, 925-928. [CrossRef] [PubMed]

4. Zurfluh, S.; Baumgartner, T.; Meier, M.A.; Ottiger, M.; Voegeli, A.; Bernasconi, L.; Neyer, P.; Mueller, B.; Schuetz, P. The role of metabolomic markers for patients with infectious diseases: Implications for risk stratification and therapeutic modulation. Expert Rev. Anti-Infect. Ther. 2018, 16, 133-142. [CrossRef] [PubMed]

5. Serkova, N.J.; Standiford, T.J.; Stringer, K.A. The Emerging Field of Quantitative Blood Metabolomics for Biomarker Discovery in Critical Illnesses. Am. J. Respir. Crit. Care Med. 2011, 184, 647-655. [CrossRef]

6. Carré, J.E.; Singer, M. Cellular energetic metabolism in sepsis: The need for a systems approach. Biochim. Biophys. Acta (BBA)_Bioenerg. 2008, 1777, 763-771. [CrossRef]

7. Beloborodova, N.V.; Olenin, A.Y.; Pautova, A.K. Metabolomic findings in sepsis as a damage of host-microbial metabolism integration. J. Crit. Care 2018, 43, 246-255. [CrossRef] [PubMed]

8. Drobnik, W.; Liebisch, G.; Audebert, F.-X.; Fröhlich, D.; Glück, T.; Vogel, P.; Rothe, G.; Schmitz, G. Plasma ceramide and lysophosphatidylcholine inversely correlate with mortality in sepsis patients. J. Lipid Res. 2003, 44, 754-761. [CrossRef]

9. Schmerler, D.; Neugebauer, S.; Ludewig, K.; Bremer-Streck, S.; Brunkhorst, F.M.; Kiehntopf, M. Targeted metabolomics for discrimination of systemic inflammatory disorders in critically ill patients. J. Lipid Res. 2012, 53, 1369-1375. [CrossRef]

10. Su, L.; Huang, Y.; Zhu, Y.; Xia, L.; Wang, R.; Xiao, K.; Wang, H.; Yan, P.; Wen, B.; Cao, L.; et al. Discrimination of sepsis stage metabolic profiles with an LC/MS-MS-based metabolomics approach. BMJ Open Respir. Res. 2014, 1, e000056. [CrossRef]

11. Claussnitzer, M.; Dankel, S.N.; Kim, K.-H.; Quon, G.; Meuleman, W.; Haugen, C.; Glunk, V.; Sousa, I.S.; Beaudry, J.L.; Puviindran, V.; et al. FTO Obesity Variant Circuitry and Adipocyte Browning in Humans. N. Engl. J. Med. 2015, 373, 895-907. [CrossRef] [PubMed]

12. Neugebauer, S.; Giamarellos-Bourboulis, E.J.; Pelekanou, A.; Marioli, A.; Baziaka, F.; Tsangaris, I.; Bauer, M.; Kiehntopf, M. Metabolite Profiles in Sepsis. Crit. Care Med. 2016, 44, 1649-1662. [CrossRef]

13. Mecatti, G.C.; Messias, M.C.F.; Paiola, R.M.S.; Angolini, C.F.F.; Cunha, I.B.D.S.; Eberlin, M.N.; de Carvalho, P. Lipidomic Profiling of Plasma and Erythrocytes From Septic Patients Reveals Potential Biomarker Candidates. Biomark. Insights 2018, 13, 1177271918765137. [CrossRef]

14. Brun, J.; A Gray, D. Targeting the ubiquitin proteasome pathway for the treatment of septic shock in patients. Crit. Care 2009, $13,311$. [CrossRef] [PubMed]

15. Berger, M.M.; Chioléro, R.L. Antioxidant supplementation in sepsis and systemic inflammatory response syndrome. Crit. Care Med. 2007, 35, S584-S590. [CrossRef]

16. Li, P.; Yin, Y.-L.; Li, D.; Kim, S.W.; Wu, G. Amino acids and immune function. Br. J. Nutr. 2007, 98, 237-252. [CrossRef] [PubMed]

17. Zhang, Y.; Yu, W.; Han, D.; Meng, J.; Wang, H.; Cao, G. L-lysine ameliorates sepsis-induced acute lung injury in a lipopolysaccharide-induced mouse model. Biomed. Pharmacother. 2019, 118, 109307. [CrossRef]

18. Mauriz, J.L.; Matilla, B.; Culebras, J.; González, P.; González-Gallego, J. Dietary glycine inhibits activation of nuclear factor kappa $\mathrm{B}$ and prevents liver injury in hemorrhagic shock in the rat. Free. Radic. Biol. Med. 2001, 31, 1236-1244. [CrossRef]

19. Zhong, Z.; Wheeler, M.D.; Li, X.; Froh, M.; Schemmer, P.; Yin, M.; Bunzendaul, H.; Bradford, B.; Lemasters, J.J. L-Glycine: A novel antiinflammatory, immunomodulatory, and cytoprotective agent. Curr. Opin. Clin. Nutr. Metab. Care 2003, 6, 229-240. [CrossRef]

20. Razak, M.A.; Begum, P.S.; Viswanath, B.; Rajagopal, S. Multifarious Beneficial Effect of Nonessential Amino Acid, Glycine: A Review. Oxidative Med. Cell. Longev. 2017, 2017, 1-8. [CrossRef]

21. Rodriguez, A.E.; Ducker, G.S.; Billingham, L.K.; Martinez, C.A.; Mainolfi, N.; Suri, V.; Friedman, A.; Manfredi, M.G.; Weinberg, S.; Rabinowitz, J.D.; et al. Serine Metabolism Supports Macrophage IL-1ß Production. Cell Metab. 2019, 29, 1003-1011.e4. [CrossRef]

22. Ma, E.H.; Bantug, G.; Griss, T.; Condotta, S.; Johnson, R.M.; Samborska, B.; Mainolfi, N.; Suri, V.; Guak, H.; Balmer, M.L.; et al. Serine Is an Essential Metabolite for Effector T Cell Expansion. Cell Metab. 2017, 25, 345-357. [CrossRef] [PubMed]

23. Mickiewicz, B.; Duggan, G.E.; Winston, B.W.; Doig, C.; Kubes, P.; Vogel, H.J. Metabolic Profiling of Serum Samples by 1H Nuclear Magnetic Resonance Spectroscopy as a Potential Diagnostic Approach for Septic Shock. Crit. Care Med. 2014, 42, 1140-1149. [CrossRef]

24. Firpo, M.R.; Mounce, B.C. Diverse Functions of Polyamines in Virus Infection. Biomol. 2020, 10, 628. [CrossRef] [PubMed]

25. Moinard, C.; Cynober, L.; De Bandt, J.-P. Polyamines: Metabolism and implications in human diseases. Clin. Nutr. 2005, 24, 184-197. [CrossRef] 
26. Sagar, N.; Tarafdar, S.; Agarwal, S.; Tarafdar, A.; Sharma, S. Polyamines: Functions, Metabolism, and Role in Human Disease Management. Med. Sci. 2021, 9, 44. [CrossRef]

27. Yoshida, M.; Kashiwagi, K.; Shigemasa, A.; Taniguchi, S.; Yamamoto, K.; Makinoshima, H.; Ishihama, A.; Igarashi, K. A Unifying Model for the Role of Polyamines in Bacterial Cell Growth, the Polyamine Modulon. J. Biol. Chem. 2004, 279, 46008-46013. [CrossRef]

28. McCann, M.; De la Rosa, M.G.; Rosania, G.; Stringer, K. L-Carnitine and Acylcarnitines: Mitochondrial Biomarkers for Precision Medicine. Metabolites 2021, 11, 51. [CrossRef]

29. Newgard, C.B. Interplay between Lipids and Branched-Chain Amino Acids in Development of Insulin Resistance. Cell Metab. 2012, 15, 606-614. [CrossRef]

30. Marik, P.E.; Bellomo, R. Stress hyperglycemia: An essential survival response! Crit. Care 2013, 17, 305-307. [CrossRef] [PubMed]

31. Tan, T.L.; Goh, Y.Y. The role of group IIA secretory phospholipase A2 (sPLA2-IIA) as a biomarker for the diagnosis of sepsis and bacterial infection in adults-A systematic review. PLoS ONE 2017, 12, e0180554. [CrossRef]

32. Van Wyngene, L.; Vandewalle, J.; Libert, C. Reprogramming of basic metabolic pathways in microbial sepsis: Therapeutic targets at last? EMBO Mol. Med. 2018, 10, e8712. [CrossRef] [PubMed]

33. Delogu, G.; Famularo, G.; Amati, F.; Signore, L.; Antonucci, A.; Trinchieri, V.; Di Marzio, L.; Cifone, M.G. Ceramide concentrations in septic patients: A possible marker of multiple organ dysfunction syndrome. Crit. Care Med. 1999, 27, 2413-2417. [CrossRef] [PubMed]

34. Opal, S.M. Endotoxins and Other Sepsis Triggers. Contrib. Nephrol. 2010, 167, 14-24. [CrossRef] [PubMed]

35. Calder, P.C. The 2008 ESPEN Sir David Cuthbertson lecture: Fatty acids and inflammation-From the membrane to the nucleus and from the laboratory bench to the clinic. Clin. Nutr. 2010, 29, 5-12. [CrossRef] [PubMed]

36. Goñi, F.M.; Alonso, A. Sphingomyelinases: Enzymology and membrane activity. FEBS Lett. 2002, 531, 38-46. [CrossRef]

37. Ahn, W.-G.; Jung, J.-S.; Kwon, H.Y.; Song, D.-K. Alteration of Lysophosphatidylcholine-Related Metabolic Parameters in the Plasma of Mice with Experimental Sepsis. Inflammation 2016, 40, 537-545. [CrossRef]

38. Umezu-Goto, M.; Kishi, Y.; Taira, A.; Hama, K.; Dohmae, N.; Takio, K.; Yamori, T.; Mills, G.B.; Inoue, K.; Aoki, J.; et al. Autotaxin has lysophospholipase D activity leading to tumor cell growth and motility by lysophosphatidic acid production. J. Cell Biol. 2002, 158, 227-233. [CrossRef]

39. Zou, C.; Synan, M.J.; Li, J.; Xiong, S.; Manni, M.L.; Liu, Y.; Chen, B.B.; Zhao, Y.; Shiva, S.; Tyurina, Y.Y.; et al. LPS impairs oxygen utilization in epithelia by triggering degradation of the mitochondrial enzyme Alcat1. J. Cell Sci. 2016, 129, 51-64. [CrossRef]

40. Pizzuto, M.; Pelegrin, P. Cardiolipin in Immune Signaling and Cell Death. Trends Cell Biol. 2020, 30, 892-903. [CrossRef]

41. Van Der Veen, J.N.; Kennelly, J.P.; Wan, S.; Vance, J.E.; Vance, D.E.; Jacobs, R.L. The critical role of phosphatidylcholine and phosphatidylethanolamine metabolism in health and disease. Biochim. et Biophys. Acta (BBA)—Biomembr. 2017, 1859, 1558-1572. [CrossRef] [PubMed]

42. Mickiewicz, B.; Tam, P.; Jenne, C.N.; Leger, C.; Wong, J.; Winston, B.W.; Doig, C.; Kubes, P.; Vogel, H.J.; Alberta Sepsis Network. Integration of metabolic and inflammatory mediator profiles as a potential prognostic approach for septic shock in the intensive care unit. Crit. Care 2015, 19, 1-12. [CrossRef]

43. HoleČek, M. Branched-chain amino acids in health and disease: Metabolism, alterations in blood plasma, and as supplements. Nutr. Metab. 2018, 15, 1-12. [CrossRef] [PubMed]

44. Mattick, J.; Kamisoglu, K.; Ierapetritou, M.G.; Androulakis, I.P.; Berthiaume, F. Branched-chain amino acid supplementation: Impact on signaling and relevance to critical illness. Wiley Interdiscip. Rev. Syst. Biol. Med. 2013, 5, 449-460. [CrossRef]

45. Tapiero, H.; Mathé, G.; Couvreur, P.; Tew, K., II. Glutamine and glutamate. Biomed. Pharmacother. 2002, 56, 446-457. [CrossRef]

46. Poeze, M.; Luiking, Y.C.; Breedveld, P.; Manders, S.; Deutz, N.E. Decreased plasma glutamate in early phases of septic shock with acute liver dysfunction is an independent predictor of survival. Clin. Nutr. 2008, 27, 523-530. [CrossRef]

47. Machado, M.C.C.; Da Silva, F.P. Hyperammonemia due to urea cycle disorders: A potentially fatal condition in the intensive care setting. J. Intensiv. Care 2014, 2, 22. [CrossRef]

48. Straaten, H.M.O.-V.; van Zanten, A.R. Glutamine supplementation in the critically ill: Friend or foe? Crit. Care 2014, 18, 143. [CrossRef] [PubMed]

49. Luiking, Y.C.; Poeze, M.; Ramsay, G.; Deutz, N.E. Reduced citrulline production in sepsis is related to diminished de novo arginine and nitric oxide production. Am. J. Clin. Nutr. 2008, 89, 142-152. [CrossRef] [PubMed]

50. Rosenthal, M.D.; Carrott, P.W.; Patel, J.; Kiraly, L.; Martindale, R.G. Parenteral or Enteral Arginine Supplementation Safety and Efficacy. J. Nutr. 2016, 146, 2594S-2600S. [CrossRef]

51. Marik, P.E. Arginine: Too much of a good thing may be bad! Crit. Care Med. 2006, 34, 2844-2847. [CrossRef]

52. Heyland, D.K.; Novak, F.; Drover, J.W.; Jain, M.; Su, X.; Suchner, U. Should Immunonutrition Become Routine in Critically Ill Patients? JAMA 2001, 286, 944-953. [CrossRef] 
53. Otto, G.P.; Neugebauer, S.; A Claus, R.; Sossdorf, M. Arginine metabolism is markedly impaired in polymicrobial infected mice. Crit. Care 2012, 16, 412. [CrossRef]

54. Druml, W.; Heinzel, G.; Kleinberger, G. Amino acid kinetics in patients with sepsis. Am. J. Clin. Nutr. 2001, 73, 908-913. [CrossRef] [PubMed]

55. Ploder, M.; Neurauter, G.; Spittler, A.; Schroecksnadel, K.; Roth, E.; Fuchs, D. Serum phenylalanine in patients post trauma and with sepsis correlate to neopterin concentrations. Amino Acids 2007, 35, 303-307. [CrossRef]

56. Pastor, C.M.; Williams, D.; Yoneyama, T.; Hatakeyama, K.; Singleton, S.; Naylor, E.; Billiar, T.R. Competition for Tetrahydrobiopterin between Phenylalanine Hydroxylase and Nitric Oxide Synthase in Rat Liver. J. Biol. Chem. 1996, 271, 24534-24538. [CrossRef] [PubMed]

57. Shi, W.; Meininger, C.J.; Haynes, T.E.; Hatakeyama, K.; Wu, G. Regulation of Tetrahydrobiopterin Synthesis and Bioavailability in Endothelial Cells. Cell Biophys. 2004, 41, 415-434. [CrossRef]

58. Schroeder, M.A.; Atherton, H.J.; Dodd, M.; Lee, P.; Cochlin, L.E.; Radda, G.K.; Clarke, K.; Tyler, D. The Cycling of Acetyl-Coenzyme A Through Acetylcarnitine Buffers Cardiac Substrate Supply. Circ. Cardiovasc. Imaging 2012, 5, 201-209. [CrossRef]

59. Jennaro, T.S.; Puskarich, M.; McCann, M.R.; Gillies, C.E.; Pai, M.P.; Karnovsky, A.; Evans, C.R.; Jones, A.E.; Stringer, K.A. Using L-Carnitine as a Pharmacologic Probe of the Interpatient and Metabolic Variability of Sepsis. Pharmacother. J. Hum. Pharmacol. Drug Ther. 2020, 40, 913-923. [CrossRef]

60. Dalli, J.; Colas, R.A.; Quintana, C.; Barragan-Bradford, D.; Hurwitz, S.; Levy, B.D.; Choi, A.M.; Serhan, C.N.; Baron, R.M. Human Sepsis Eicosanoid and Proresolving Lipid Mediator Temporal Profiles. Crit. Care Med. 2017, 45, 58-68. [CrossRef] [PubMed]

61. Langley, R.J.; Tsalik, E.L.; van Velkinburgh, J.C.; Glickman, S.W.; Rice, B.J.; Wang, C.; Chen, B.; Carin, L.; Suarez, A.; Mohney, R.P.; et al. An Integrated Clinico-Metabolomic Model Improves Prediction of Death in Sepsis. Sci. Transl. Med. 2013, 5, 195ra95. [CrossRef]

62. Rogers, A.; McGeachie, M.; Baron, R.M.; Gazourian, L.; Haspel, J.A.; Nakahira, K.; Fredenburgh, L.E.; Hunninghake, G.M.; Raby, B.A.; Matthay, M.A.; et al. Metabolomic Derangements Are Associated with Mortality in Critically Ill Adult Patients. PLoS ONE 2014, 9, e87538. [CrossRef] [PubMed]

63. Chung, K.-P.; Chen, G.-Y.; Chuang, T.-Y.; Huang, Y.-T.; Chang, H.-T.; Chen, Y.-F.; Liu, W.-L.; Chen, Y.-J.; Hsu, C.-L.; Huang, M.-T.; et al. Increased Plasma Acetylcarnitine in Sepsis Is Associated With Multiple Organ Dysfunction and Mortality. Crit. Care Med. 2019, 47, 210-218. [CrossRef]

64. Wang, J.; Sun, Y.; Teng, S.; Li, K. Prediction of sepsis mortality using metabolite biomarkers in the blood: A meta-analysis of death-related pathways and prospective validation. BMC Med. 2020, 18, 1-15. [CrossRef]

65. Huang, S.-S.; Lin, J.-Y.; Chen, W.-S.; Liu, M.-H.; Cheng, C.-W.; Cheng, M.-L.; Wang, C.-H. Phenylalanine- and leucine-defined metabolic types identify high mortality risk in patients with severe infection. Int. J. Infect. Dis. 2019, 85, 143-149. [CrossRef]

66. Winkler, M.S.; Nierhaus, A.; Rösler, G.; Lezius, S.; Harlandt, O.; Schwedhelm, E.; Böger, R.H.; Kluge, S. Symmetrical (SDMA) and asymmetrical dimethylarginine (ADMA) in sepsis: High plasma levels as combined risk markers for sepsis survival. Crit. Care 2018, 22, 216. [CrossRef]

67. Ekremoğlu, M.; Türközkan, N.; Erdamar, H.; Kurt, Y.; Yaman, H. Protective effect of taurine on respiratory burst activity of polymorphonuclear leukocytes in endotoxemia. Amino Acids 2006, 32, 413-417. [CrossRef]

68. Chiarla, C.; Giovannini, I.; Siegel, J.H.; Boldrini, G.; Castagneto, M. The Relationship between Plasma Taurine and Other Amino Acid Levels in Human Sepsis. J. Nutr. 2000, 130, 2222-2227. [CrossRef] [PubMed]

69. Elmokadem, E.M.; Sabri, N.A.; Roshdy, T.A.; Hasanin, A.M. Clinical outcomes study of critically-ill septic patients given taurine supplemented enteral nutrition. Int. J. Pharm. Sci. Res. 2015, 6, 3544-3553. [CrossRef]

70. Ploder, M.; Spittler, A.; Schroecksnadel, K.; Neurauter, G.; Pelinka, L.E.; Roth, E.; Fuchs, D. Accelerated Tryptophan Degradation in Trauma and Sepsis Patients is Related to Pro-inflammatory Response and to the Diminished in vitro Response of Monocytes. Pteridines 2009, 20, 54-61. [CrossRef]

71. Changsirivathanathamrong, D.; Wang, Y.; Rajbhandari, D.; Maghzal, G.J.; Mak, W.M.; Woolfe, C.; Duflou, J.; Gebski, V.; dos Remedios, C.G.; Celermajer, D.S.; et al. Tryptophan metabolism to kynurenine is a potential novel contributor to hypotension in human sepsis. Crit. Care Med. 2011, 39, 2678-2683. [CrossRef] [PubMed]

72. Zulpaite, R.; Miknevicius, P.; Leber, B.; Strupas, K.; Stiegler, P.; Schemmer, P. Tryptophan Metabolism via Kynurenine Pathway: Role in Solid Organ Transplantation. Int. J. Mol. Sci. 2021, 22, 1921. [CrossRef] [PubMed]

73. Jenkins, T.A.; Nguyen, J.C.D.; Polglaze, K.E.; Bertrand, P.P. Influence of Tryptophan and Serotonin on Mood and Cognition with a Possible Role of the Gut-Brain Axis. Nutrients 2016, 8, 56. [CrossRef]

74. Telias, I.; Wilcox, M.E. Sleep and Circadian Rhythm in Critical Illness. Crit. Care 2019, 23, 1-8. [CrossRef]

75. Panyushkina, A.; Matyushkina, D.; Pobeguts, O. Understanding Stress Response to High-Arsenic Gold-Bearing Sulfide Concentrate in Extremely Metal-Resistant Acidophile Sulfobacillus thermotolerans. Microorganisms 2020, 8, 1076. [CrossRef]

76. Lambden, S. Bench to bedside review: Therapeutic modulation of nitric oxide in sepsis-An update. Intensiv. Care Med. Exp. 2019, 7, 1-14. [CrossRef]

77. Böger, R.H. The emerging role of asymmetric dimethylarginine as a novel cardiovascular risk factor. Cardiovasc. Res. 2003, 59, 824-833. [CrossRef]

78. Yoshikai, Y. Roles of prostaglandins and leukotrienes in acute inflammation caused by bacterial infection. Curr. Opin. Infect. Dis. 2001, 14, 257-263. [CrossRef] [PubMed] 
79. Aronoff, D.M. Cyclooxygenase Inhibition in Sepsis: Is There Life after Death? Mediat. Inflamm. 2012, 2012, 1-7. [CrossRef]

80. Bindu, S.; Mazumder, S.; Bandyopadhyay, U. Non-steroidal anti-inflammatory drugs (NSAIDs) and organ damage: A current perspective. Biochem. Pharmacol. 2020, 180, 114147. [CrossRef]

81. Srisawat, N.; Kulvichit, W.; Mahamitra, N.; Hurst, C.; Praditpornsilpa, K.; Lumlertgul, N.; Chuasuwan, A.; Trongtrakul, K.; Tasnarong, A.; Champunot, R.; et al. The epidemiology and characteristics of acute kidney injury in the Southeast Asia intensive care unit: A prospective multicentre study. Nephrol. Dial. Transplant. 2020, 35, 1729-1738. [CrossRef]

82. Trongtrakul, K.; Sawawiboon, C.; Wang, Y.; Chitsomkasem, A.; Limphunudom, P.; Kurathong, S.; Prommool, S.; Trakarnvanich, T.; Srisawat, N. Acute kidney injury in critically ill surgical patients: Epidemiology, risk factors and outcomes. Nephrology 2017, 24, 39-46. [CrossRef] [PubMed]

83. Adams, S.; Hoppel, C.L.; Lok, K.H.; Zhao, L.; Wong, S.W.; Minkler, P.E.; Hwang, D.H.; Newman, J.; Garvey, W.T. Plasma Acylcarnitine Profiles Suggest Incomplete Long-Chain Fatty Acid $\beta$-Oxidation and Altered Tricarboxylic Acid Cycle Activity in Type 2 Diabetic African-American Women. J. Nutr. 2009, 139, 1073-1081. [CrossRef]

84. Garcia-Alvarez, M.; Marik, P.; Bellomo, R. Sepsis-associated hyperlactatemia. Crit. Care 2014, 18, 1-11. [CrossRef]

85. Beloborodova, N.; Sarshor, Y.N.; Bedova, A.Y.; Chernevskaya, E.; Pautova, A.K. Involvement of Aromatic Metabolites in the Pathogenesis of Septic Shock. Shock 2018, 50, 273-279. [CrossRef]

86. Liu, Z.; Triba, M.N.; Amathieu, R.; Lin, X.; Bouchemal, N.; Hantz, E.; Le Moyec, L.; Savarin, P. Nuclear magnetic resonance-based serum metabolomic analysis reveals different disease evolution profiles between septic shock survivors and non-survivors. Crit. Care 2019, 23, 1-12. [CrossRef] [PubMed]

87. Liu, Z.; Yin, P.; Amathieu, R.; Savarin, P.; Xu, G. Application of LC-MS-based metabolomics method in differentiating septic survivors from non-survivors. Anal. Bioanal. Chem. 2016, 408, 7641-7649. [CrossRef]

88. Ferrario, M.; Cambiaghi, A.; Brunelli, L.; Giordano, S.; Caironi, P.; Guatteri, L.; Raimondi, F.; Gattinoni, L.; Latini, R.; Masson, S.; et al. Mortality prediction in patients with severe septic shock: A pilot study using a target metabolomics approach. Sci. Rep. 2016, 6, 20391. [CrossRef] [PubMed]

89. Cambiaghi, A.; Díaz, R.; Martinez, J.B.; Odena, A.; Brunelli, L.; Caironi, P.; Masson, S.; Baselli, G.; Ristagno, G.; Gattinoni, L.; et al. An Innovative Approach for The Integration of Proteomics and Metabolomics Data In Severe Septic Shock Patients Stratified for Mortality. Sci. Rep. 2018, 8, 6681. [CrossRef]

90. Garcia-Simon, M.; Morales, J.M.; Modesto-Alapont, V.; Gonzalez-Marrachelli, V.; Vento-Rehues, R.; Jorda-Miñana, A.; BlanquerOlivas, J.; Monleon, D. Prognosis Biomarkers of Severe Sepsis and Septic Shock by 1H NMR Urine Metabolomics in the Intensive Care Unit. PLoS ONE 2015, 10, e0140993. [CrossRef]

91. Evans, C.R.; Karnovsky, A.; Puskarich, M.; Michailidis, G.; Jones, A.E.; Stringer, K.A. Untargeted Metabolomics Differentiates 1-Carnitine Treated Septic Shock 1-Year Survivors and Nonsurvivors. J. Proteome Res. 2019, 18, 2004-2011. [CrossRef] [PubMed]

92. Tsikas, D. Urinary Dimethylamine (DMA) and Its Precursor Asymmetric Dimethylarginine (ADMA) in Clinical Medicine, in the Context of Nitric Oxide (NO) and Beyond. J. Clin. Med. 2020, 9, 1843. [CrossRef]

93. Wexler, O.; Gough, M.S.; Morgan, M.A.M.; Mack, C.M.; Apostolakos, M.J.; Doolin, K.P.; Mooney, R.A.; Arning, E.; Bottiglieri, T.; Pietropaoli, A.P. Methionine Metabolites in Patients With Sepsis. J. Intensiv. Care Med. 2016, 33, 37-47. [CrossRef] [PubMed]

94. Tvrzicka, E.; Kremmyda, L.-S.; Stankova, B.; Zak, A. Fatty acids as biocompounds: Their role in human metabolism, health and disease-a review. Part 1: Classification, dietary sources and biological functions. Biomed. Pap. 2011, 155, 117-130. [CrossRef]

95. Nuzzo, E.; Berg, K.M.; Andersen, L.W.; Balkema, J.; Montissol, S.; Cocchi, M.N.; Liu, X.; Donnino, M.W. Pyruvate Dehydrogenase Activity Is Decreased in the Peripheral Blood Mononuclear Cells of Patients with Sepsis. A Prospective Observational Trial. Ann. Am. Thorac. Soc. 2015, 12, 1662-1666. [CrossRef]

96. Zorov, D.B.; Juhaszova, M.; Sollott, S.J. Mitochondrial Reactive Oxygen Species (ROS) and ROS-Induced ROS Release. Physiol. Rev. 2014, 94, 909-950. [CrossRef]

97. Martínez-Reyes, I.; Chandel, N.S. Mitochondrial TCA cycle metabolites control physiology and disease. Nat. Commun. 2020, 11, 1-11. [CrossRef] [PubMed]

98. Galley, H.F. Oxidative stress and mitochondrial dysfunction in sepsis. Br. J. Anaesth. 2011, 107, 57-64. [CrossRef]

99. Puskarich, M.A.; Finkel, M.A.; Karnovsky, A.; Jones, A.E.; Trexel, J.; Harris, B.N.; Stringer, K.A. Pharmacometabolomics oflCarnitine Treatment Response Phenotypes in Patients with Septic Shock. Ann. Am. Thorac. Soc. 2015, 12, 46-56. [CrossRef] [PubMed]

100. Cambiaghi, A.; Pinto, B.B.; Brunelli, L.; Falcetta, F.; Aletti, F.; Bendjelid, K.; Pastorelli, R.; Ferrario, M. Characterization of a metabolomic profile associated with responsiveness to therapy in the acute phase of septic shock. Sci. Rep. 2017, 7, 1-16. [CrossRef]

101. Ruggieri, A.J.; Levy, R.J.; Deutschman, C.S. Mitochondrial Dysfunction and Resuscitation in Sepsis. Crit. Care Clin. 2010, 26, 567-575. [CrossRef] [PubMed]

102. Maslove, D.M.; Wong, H.R. Gene expression profiling in sepsis: Timing, tissue, and translational considerations. Trends Mol. Med. 2014, 20, 204-213. [CrossRef] [PubMed]

103. Cao, Z.; Robinson, R.A.S. The role of proteomics in understanding biological mechanisms of sepsis. Proteom.-Clin. Appl. 2013, 8 , 35-52. [CrossRef] [PubMed] 